\title{
Understanding farm trajectories and development pathways: Two decades of change in southern Mali
}

\author{
Gatien N. Falconnier ${ }^{\text {a,b,* }}$, Katrien Descheemaeker ${ }^{\text {b }}$, Thomas A. Van Mourik ${ }^{c}$, \\ Ousmane M. Sanogo ${ }^{\mathrm{d}}$, Ken E. Giller ${ }^{\mathrm{b}}$ \\ a International Crops Research Institute for the Semi-Arid Tropics (ICRISAT), BP 320 Bamako, Mali \\ b Plant Production Systems, Wageningen University, PO Box 430, 6700 AK Wageningen, The Netherlands \\ ${ }^{c}$ Helen Keller International, Africa Regional Office, PO Box 29.898, 11 Nord Foire Azur, Yoff, Dakar, Senegal \\ d Institut d'Economie Rurale (IER), ESPGRN-Sikasso, P.O. Box 186 Sikasso, Mali
}

\section{A R T I C L E I N F O}

\section{Article history:}

Received 15 September 2014

Received in revised form 11 July 2015

Accepted 20 July 2015

Available online $\mathrm{xxx}$

\section{Keywords:}

Longitudinal study

Farm typology

Land productivity

Labour productivity

Food self-sufficiency

\begin{abstract}
A B S T R A C T
Institutional support for smallholders has been the motor for the expanding cotton production sector in southern Mali since the 1970s. Smallholder farms exhibit diverse resource endowments and little is known on how they benefit from and cope with changes in this institutional support. In this paper we explore farm trajectories during two decades (1994 to 2010) and their link with farm resource endowment and government support. We distinguished a favourable period for cotton production and an unfavourable period during which institutional support collapsed. A panel survey that monitored 30 farms in the Koutiala district in southern Mali over this period was analysed. Based on indicators of resource endowment and using Ascending Hierarchical Classification (AHC), farms were grouped into four types: High Resource Endowed farms with Large Herds (HRE-LH), High Resource Endowed (HRE) farms, Medium Resource Endowed (MRE) farms and Low Resource Endowed (LRE) farms. Average yield, labour productivity and food self-sufficiency status of each type were calculated. Farms remaining in the same type were classified as 'hanging in', while farms moving to a type of higher yields, labour productivity and food self-sufficiency status were classified as 'stepping up', and farms following the opposite trajectory of deteriorating farming conditions were classified as 'falling down'. The LRE farms differed from all other farm types due to lower yields, while both LRE and HRE farms differed from the MRE and HRE-LH farm types due to a combination of less labour productivity and less food self-sufficiency. During those two decades, $17 \%$ of the farms 'stepped up', while $70 \%$ of the farms remained 'hanging in', and only $13 \%$ of the farms 'fell down'. We found no obvious negative impact of the collapse of government support on farm trajectories. For MRE, HRE and HRELH farms, average N and P use intensity increased from 1994 to 2004 and then decreased during the following cotton crisis. On the other hand, organic fertilizer use intensity increased continuously over the entire monitoring period for HRE-LH and MRE farms. Crop yields did not change significantly over time for any farm type and labour productivity decreased. We discuss how technical options specific for different farm types (increase in farm equipment, sale of cereals, incorporation of legumes and intensification of milk production) and broader institutional change (improvement in finance system and infrastructure, tariffs) can enhance 'step up' trajectories for farming households and avoid stagnation ('hanging in') of the whole agricultural sector.
\end{abstract}

C 2015 Elsevier B.V. All rights reserved.

\section{Introduction}

Cotton production and export from West Africa grew rapidly over the last four decades and government support provided inputs for more than one million cotton-producing smallholder farm families (Gabre-Madhin and Haggblade, 2004). In Southern Mali, cotton

\footnotetext{
* Corresponding author at: International Crops Research Institute for the Semi-Arid Tropics (ICRISAT), BP 320 Bamako, Mali.

E-mail addresses: gatien.falconnier@wur.nl, falconniergatien@yahoo.fr (G.N. Falconnier).
}

earnings have been used to invest in livestock, providing animal traction (Dufumier and Bainville, 2006) and contributing to enhanced land and labour productivity and food self-sufficiency (Tefft, 2010). Smallholder farms are diverse in their resource endowment and production objectives (Giller et al., 2011), and respond differently to changing conditions, with the poorest often left behind (Hazell et al., 2010; Valbuena et al., 2014). In West Africa, fluctuating cotton world prices and restructuring or privatization of state-owned companies intensify uncertainties for farmers (Fok, 2010). Little is known of what types of farm households benefited most from institutional support for cotton production, nor of how farmers cope with changing production conditions. Farm typologies can help in understanding farmer diversity and 
allow analysis of the impact of development interventions (Iraizoz et al., 2007). Typology studies have revealed links between the current farm resource endowment and soil fertility status (Tittonell et al., 2010; Zingore et al., 2007), adaptation strategy (Zorom et al., 2013), land productivity, profitability and labour productivity (Senthilkumar et al., 2012). Yet most studies depend on single snapshots in time from oneoff household surveys (Senthilkumar et al., 2012; Tittonell et al., 2010; Zorom et al., 2013) and do not allow analysis of how farms cope in response to fluctuating external forces. In a developed country context, based on detailed agricultural censuses and land use monitoring datasets, Mignolet et al. (2007) showed the link between the European Common Agricultural Policy and specialization of farms towards cash crops and disappearance of livestock at regional scale. Landscape spatial organization dynamics in link with farmer decisions, market conditions and public policies has also been well documented in various European countries (Schaller et al., 2011; Stoate et al., 2009). Dynamic farm typologies in Guadeloupe (Chopin et al., 2014) showed how access to irrigation schemes can trigger diversification of farm systems. In the African smallholder context, studies explaining trends in agricultural systems are rare. Some explored the long-term impact on land use change of political context, demography and markets at village or regional scale (Benjaminsen et al., 2010; Ebanyat et al., 2010; Sassen et al., 2013). Others relied on individual recall of household heads to understand how they cope in response to changing production conditions (Dufumier and Bainville, 2006).

A longitudinal survey (i.e. repeated observations of the same variables over time) monitored 30 farms in the cotton zone of Southern Mali from 1994 until 2010 (Djouara et al., 2005; Sanogo et al., 2010). This dataset provides a rich basis to explore the trajectories of farm development in terms of land and labour productivity and food selfsufficiency over two decades in relation to the influence of external factors. We explored two hypotheses, namely that: (i) stratification according to farm resource endowment explains heterogeneity in land and labour productivity and food self-sufficiency and (ii) favourable cotton prices stimulated farm development while unfavourable cotton prices had the opposite impact. We use this analysis to propose options for sustainable intensification that may be suitable to the different types of smallholder farms in Southern Mali.

\section{Materials and methods}

\subsection{Description of the different steps of the method}

The methodology for this longitudinal study includes five steps: (i) the building of a farm typology using a set of key resource endowment variables in the first year of the monitoring, (ii) the generation of fixed thresholds for the classification of farms in the remaining years, (iii) the computation of indicators of land productivity (crop yields), labour productivity and food self-sufficiency for each farm for each year, (iv) the assessment and quantification of farm trajectories i.e. change from a type to another, and ( $v$ ) a focus group discussion with farmers in order to validate the typology and add insights in the different trajectories. Variables explaining yield variability between farms and farm type can be collected/computed and include agro-ecological conditions, input use (e.g. mineral and organic fertilizer), land investment (e.g. soil bunds, trees) (Gigou et al., 2006), access to information (extension services), services (e.g. credit) and markets for inputs and outputs. Food self-sufficiency can be assessed either by measuring the number of months per year when the household is food self-sufficient (Tittonell et al., 2010; Valbuena et al., 2014) or by comparing the sum of basic energy requirements of the different members of the household to on-farm cereal production (Andrieu et al., 2015; Paassen et al., 2011; Tittonell et al., 2009).

\subsection{Study area}

The study area is located in Koutiala district in the cotton zone of Southern Mali, between the $800 \mathrm{~mm}$ and $1000 \mathrm{~mm}$ isohyets. Yearly rainfall fluctuates from 600 to $1400 \mathrm{~mm}$ (Fig. 1a). The population pressure is relatively high compared with the rest of the country, reaching 70 people $\mathrm{km}^{-2}$ (Soumaré et al., 2008). The dominant crops are cotton, maize, sorghum, millet and groundnut where organic fertilizer is applied on cotton, and mineral fertilizer solely on cotton and maize (Kanté, 2001). Farmers rely largely on cotton, maize and livestock for income and on maize, sorghum and millet as staple foods. Crop-livestock interactions are a key element of the farming systems of the area, accounting for good cotton and cereal yields, food self-sufficiency and income generation. Draught power allows for improved timeliness of farming operations to cope with the erratic distribution of rainfall, while application of livestock manure has positive feedbacks on crop productivity (Kanté, 2001).

\subsection{Dataset}

We analysed a dataset collected by the 'Equipe Système de Production et Gestion des Resources Naturelles (ESPGRN)' of the Malian Institut d'Economie Rural (IER). This dataset contains 17 years (1994-2010) of data on household resource endowment (total cropped land and area of the different crops, composition of the household, animals owned, number of tools), input use (mineral fertilizer, herbicides, pesticides and manure) and farmer-estimated yields (cotton, maize, sorghum and millet) for 32 farms from three villages of the Koutiala area. Of this sample, 12 farms were located in the village Try $\left(12^{\circ} 16^{\prime} \mathrm{N}\right.$ and $\left.5^{\circ} 23^{\prime} \mathrm{W}\right), 8$ farms in M'Peresso $\left(12^{\circ} 17^{\prime} \mathrm{N}\right.$ and $\left.5^{\circ} 20^{\prime} \mathrm{W}\right)$ and 10 farms in N'Goukan $\left(12^{\circ} 21^{\prime} \mathrm{N}\right.$ and $\left.5^{\circ} 19^{\prime} \mathrm{W}\right)$. The farms were selected purposively

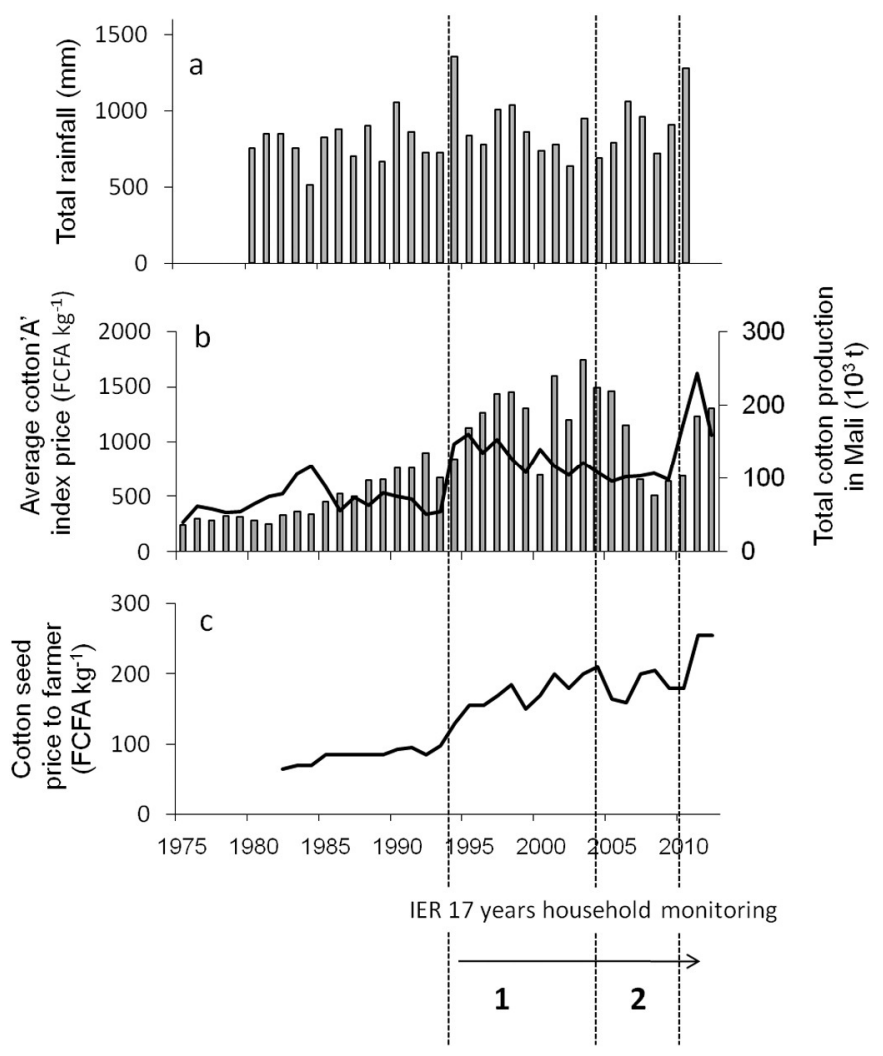

Fig. 1. The context of rainfall and cotton price in the Koutiala area, showing two distinct periods within the household monitoring period (1994-2010). (a) Annual rainfall. (b) Average cotton ' $A$ ' index price (line) and total cotton production in Mali (bars). (c) Cotton seed price paid to the farmer. Period $1=$ the favourable context for cotton production, period $2=$ the unfavourable period when support from CMDT collapsed. 
according to a typology established by IER (IER, 1988) that distinguished four farm types (A, B, C, D) according to oxen endowment. In 1994, A, B, C and D farm types constituted 31,53, 6, and 9\% of the sample respectively. These shares correspond to the relative frequency of the farm types found in the broader cotton zone at that period (Tefft, 2010). Two farms were excluded from our analysis because of incomplete data and consequently, our analysis was carried out on 30 farms from 1994 to 2010. Surveys were conducted on an annual basis between 1994 and 2010 by an IER extension worker based at each site. Absolute values of production need to be interpreted cautiously as they were based on farmers' estimates. However thanks to frequent interactions with the CMDT, farmers usually accurately know the size of their different fields (ha). Cotton is weighed by the CMDT so for this crop the measurement is precise. Finally, because the same farmers were interviewed over all these years, trends over time and the relative differences between farms can be interpreted with confidence.

We characterized the economic and institutional cotton context over the past three decades based on an analysis of changes in Malian cotton production (US Department of Agriculture PSD database, http://www.indexmundi.com/agriculture/?country=ml\&commodity $=$ cotton\&graph = production, last accessed 01/27/ 2014), cotton world prices (National Cotton Council of America, http://www.cotton.org/ econ/prices/monthly.cfm, last accessed 01/27/ 2014) and prices paid to farmers (sourced from CMDT). Prices were expressed in CFA francs using historical rates. Trends of average cotton yield were derived from Blanchard (2010) and records of annual rainfall were acquired from Meteo Mali.

\subsection{Establishment of a farm typology}

In order to define farm types based on resource endowment, we used the farm data of the first year (1994) of the monitoring period as the baseline. The farm types were derived from a cluster analysis, for which six variables describing basic farm resources and defining potential land and labour productivity were retained (Dufumier and Bainville, 2006; IER, 1988). Those included (1) total cropped land (ha), (2) number of workers, (3) total household size, (4) herd size, expressed in Tropical Livestock Units (TLU) of $250 \mathrm{~kg}$, (5) number of oxen and (6) number of draught tools (ploughs, weeders and sowing machines). Number of workers was calculated by counting 1 worker for adult men and women (15-60 years old), and 0.5 for young people (7-15 years old) and the elderly ( $>60$ years). Though total household size and cropped land were strongly correlated, they represented different attributes of the household and were both retained. The number of workers, oxen and draught tools are good indicators for timeliness of cropping operations and planting in particular, while the herd size is an indicator of the potential transfer of fertility from rangeland to cropland as well as the recycling of fertility within cropland. The distribution of each variable among the 30 farms in 1994 was analysed to identify outliers. Excluding those outliers, cluster analysis using Ascending Hierarchical Classification (AHC) (Köbrich et al., 2003) was carried out. Following Pacini et al. (2014) we normalized the data ((initial value - mean of the variable) / standard deviation of the variable) before the AHC to avoid the influence of different levels of variation due to the unit of measurement. In order to define cut-off values for the classification of farms, we used boxplots for the identification of variables with distinctive power. For each variable and each group of two farm types, we analysed the maximum of the variable for the farm type with the lowest median, and the minimum of the variable for the farm type with the highest median. When there was no overlap between the maximum and the minimum, we took the maximum as the cut-off between the two farm types. When there was an overlap, we did not define any cut-off. Considering the cut-offs, we developed a simple decision tree to classify each farm into a type for the remaining years of the monitoring period (1995-2010).

\subsection{Calculation of indicators of farm productivity and food self-sufficiency}

Crop yields were used as indicators of land productivity. In our study, all the farms were situated in a similar agro-ecological zone (i.e. they originated from three villages not more than $10 \mathrm{~km}$ apart) so we did not consider it as an explaining factor of farm productivity. Indicators of soil fertility like soil nutrient content and soil type were not available in the panel dataset. The lack of information on land investment and institutional factors in the dataset precluded an analysis of the effects on yields of these explaining factors. However, services provided by CMDT, i.e. access to credit for fertilizer, advice from village-based field agents and the offtake of all cotton production, were similar in all the villages (Degnbol, 2001). Hence, cotton production (share of cotton in the cropped land) was used as a key indicator of access to information, service and market and its influence on farm productivity was assessed.

In our dataset, total cropped land, crop area, crop production and input use were recorded based on farmers' estimates during the 17 years of the monitoring period. We calculated average input use (for nitrogen, phosphorus, potassium, and organic fertilizer), land and labour productivity (for cotton, maize, sorghum and millet), grain production per household member, and percent fulfilment of household calorific need for each farm type and year, using arithmetic means (Supplementary materials, Table 1 ). As crop area and household size did not vary widely within a type, it was assumed that each farm contributed equally to the type average. Labour productivity was assessed as the total crop production per worker. Hired labour was not included in the computation of the number of workers, as it represents a minor part of the total on-farm available labour (Coulibaly, 2011). Production of calories was computed based on household cereal production, considering an average supply of $3500 \mathrm{kcal} \mathrm{kg}^{-1}$ maize, sorghum and millet grain (Muhammad-Lawal and Omotesho, 2008; FAO: http://www.fao. org/docrep/t0818e/T0818E0b.htm, last accessed 23/06/2015). For household calorific needs, we considered specific daily needs for different age and sex groups following Britten et al. (2006) data. Percent fulfilment of household calorific need is further referred as food selfsufficiency. We did not take into account livestock products in the food self-sufficiency computation, as the data was not available in the panel data and the frequency of meat and milk consumption is low in the rural setting of southern Mali (Generoso, 2015). Our computation of food self-sufficiency further deliberately ignored food purchases, as it would then become a measure of 'food security' rather than food self-sufficiency. This choice was motivated by (i) the absence of data on food purchase in the panel dataset, and (ii) knowledge that the farmers' main objective in the area is to achieve food self-sufficiency (Paassen et al., 2011) given the few off-farm opportunities to generate cash to buy food.

Given the skewness of the data, the non-parametric Kruskal Wallis test was used to test for differences between indicator means for each farm type. When significant differences were found, post hoc pairwise comparisons were performed using a probability of $<0.05$.

\subsection{Analysis of farm trajectories}

The trajectory of each farm was analysed during three periods of six years each: a) 1994-1999, b) 1999-2004, c) 2004-2009 and for those three periods combined (1994-2009). For each period and farm, we compared the farm type at the beginning and at the end of the period. Farms remaining in the same type were classified as 'hanging in' (Dorward et al., 2009), implying no change in farm structure. Farms moving to a type of higher land and labour productivity and food selfsufficiency status were classified as 'stepping up' (Dorward et al., 2009), as their farming and living conditions had improved. Farms following the opposite trajectory of deteriorating farming conditions such as decreased labour productivity and food self-sufficiency were classified as 'falling down'. 


\subsection{Focus group discussion with farmers}

We discussed the results of the farm typology and the analyses of trajectories with farmers. In total 22 farmers from neighbouring villages participated in the discussion. A survey prior to the group discussion allowed for the selection and invitation of farmers who were distributed equally among farm types. Before the discussion, a poster for each farm type was presented with drawings of the average resources. After presentation of the posters, in order to validate the farm typology, farmers were asked if they could recognize themselves and their households in the farm types (i.e. determine to which farm type they belong). Eventually farmers were asked to comment on possible explanations for the different farm trajectories.

\section{Results}

\subsection{Cotton context}

Two main periods characterizing the economic and institutional context for cotton production were distinguished (Fig. 1b, c). The first period, from 1975 to 2004, we refer to as the "favourable context for cotton production". During this period, Malian cotton production increased. This was mainly due to the increasing number of cotton producers under the supervision of the Compagnie Malienne pour le Développement des Textiles (CMDT), the state-owned company. The CMDT offered a guaranteed and subsidized price for cotton, credit for fertilizers and equipment (ploughs, carts and oxen), and improved varieties. Average cotton yield continuously increased from 1975 to 1990 , reaching $1.2 \mathrm{t} \mathrm{ha}^{-1}$. From 1990 to 2004 , cotton yields declined slightly to $1 \mathrm{tha}^{-1}$ in 2004.

During the 2004-2010 period, cotton production fell when CMDT went bankrupt. We refer to this period (2004-2010) as the "unfavourable period when support from CMDT collapsed". From 1984 until 2010, the cotton world price decreased steadily (in 1994, the local currency (FCFA) was devalued, which artificially raised the local cotton price). CMDT subsidized the price given to Malian farmers to offset the decrease in the world price and to sustain production, but this led to the bankruptcy of CMDT in 2004. The bankruptcy led to cessation of the price subsidy, delays in payment and fertilizer delivery in 2005, resulting in farmers' distrust of CMDT and a decline of cotton production in the subsequent years. During this unfavourable period cotton yield stagnated at around $0.9 \mathrm{t} \mathrm{ha}^{-1}$.

During the past few years (2011-2012), the world market cotton price has increased sharply due to a drought in China, the largest cotton producing country in the world. Cotton production in Southern Mali has again increased and the CMDT has been offering good prices to regain the trust of the farmers.

\subsection{Farm typology}

The distribution of the six variables describing farm resources among the 30 farms in 1994 showed three farms with outlier values for herd size (Supplementary materials, Fig. 2). The cluster analysis carried out on the 27 remaining farms resulted in three clusters (Supplementary materials, Fig. 3): Low Resource Endowed (LRE) farms, Medium Resource Endowed (MRE) farms, and High Resource Endowed (HRE) farms. The three farms with outlier values for herd size were classified as High Resource Endowed farms with Large Herds (HRE-LH). The boxplot analysis showed that the cut-off value discriminating HRE-LH from HRE farms was a herd size of 22.4 TLU. Farms were classified as HRE rather than MRE if the number of workers was higher than 9.5. Herd size $>2.2$ TLU, total cropped land $>5.8$ ha and draft tools $>2$ together discriminated MRE farms from LRE farms (Supplementary materials, Figs. 4, 5). Farms were classified as MRE when they fulfilled at least 2 of the 3 criteria distinguishing MRE from LRE.
The MRE farms constituted the majority of the farms ( $50 \%$ of the sample) in 1994, followed by the HRE farms (23\% of the sample), while LRE and HRE-LH constituted $17 \%$ and $10 \%$ of the sample respectively (Table 1 ). Analysis of farm type distribution in 4 villages in the Koutiala district that were exhaustively sampled in 2006 showed that these villages were composed on average of $19,40,28$, and $13 \%$ of LRE, MRE, HRE and HRE-LH farms respectively, a share that is similar to the share of the SEP survey $(13,40,30,17 \%)$.

\subsection{Yields, labour productivity and food self-sufficiency}

From 1994 to 2010, the number of MRE farms fell by six (40\%), whereas the number of HRE farms increased by four (57\%). Over the same period, the number of LRE farms increased by two (40\%), whereas the number of HRE-LH remained constant. From 1994 to 2010 and for the entire sample, the household size and average number of workers per household increased ( $33 \%$ and $52 \%$ respectively), while the total cropped land area remained constant. Consequently, the average number of workers per ha almost doubled (Table 1).

There was a strong link between resource endowment and land productivity (Table 2). Average input use intensity (mineral and organic fertilizer) was significantly less for LRE compared with the other farm types. LRE farms achieved lower land productivity for all crops than the other farm types. Both MRE and HRE farms used similar amounts of mineral and organic fertilizer inputs and had higher land productivity than LRE farms. The best land productivity for all crops was obtained by HRE-LH farms.

The lower labour productivity of LRE and HRE farms coincided with a smaller oxen worker ${ }^{-1}$ ratio (Table 2). HRE farms had a larger number of workers compared with MRE farms, but less investment in oxen and lower labour productivity compared to MRE farms. In contrast, the large cattle herd of HRE-LH farms, providing sufficient oxen to complete farming operations in a timely manner, corresponded with a better labour productivity of this type over the monitoring period.

All farm types were able to fulfil their household calorific needs most of the time (Fig. 2). However, LRE farms and HRE farms were more often close to or below the self-sufficiency threshold compared with MRE and HRE-LH farm types. When considering only on-farm cereal production during the monitoring period, LRE farms were unable to achieve food self-sufficiency in three years and HRE farms in two years, compared with one year for MRE. HRE-LH farms were food self-sufficient throughout. LRE farms showed much higher year-to-year fluctuations in food self-sufficiency as compared with the other farm types (Fig. 2), and HRE had the least average grain production per capita over the monitoring period (Table 2). Logically, the two farm types with low labour productivity (LRE, HRE) also were less food self-sufficient (they more often fell below the $100 \%$ fulfilment threshold), as the number of workers is closely related to the number of household members.

As a result, the LRE farms differ from all other farm types due to their lower land productivity, while both LRE and HRE farms differ from the MRE and HRE-LH farm types due to a combination of less labour productivity and less food self-sufficiency (Fig. 3). In other words, whereas higher resource endowment goes hand in hand with greater land productivity, it does not correlate directly with labour productivity and food self-sufficiency.

\subsection{Farm trajectories: transition from a type to another}

Overall, one third of the farms transitioned from one type to another during the monitoring period, either 'stepping up' or 'falling down' (Table 3). Almost two thirds of the farms remained 'hanging in' or 'stepped up' to higher land and labour productivity, whereas a third of the farms experienced lower land and labour productivity while 'hanging in' or 'falling down'. There was no obvious negative impact of the collapse of CMDT on farm trajectories: more farms 'stepped up' and 
Table 1

Characteristics of the four farm types (average with standard deviation in brackets) in 1994 and 2010 (TLU = Tropical Livestock Unit of $250 \mathrm{~kg}$ ).

\begin{tabular}{|c|c|c|c|c|c|c|c|c|c|c|c|c|c|c|}
\hline Year & Farm type & & $\begin{array}{l}\text { Number } \\
\text { of farms }\end{array}$ & $\begin{array}{l}\text { Total cropped } \\
\text { land (ha) }\end{array}$ & $\begin{array}{l}\text { Number } \\
\text { of workers }\end{array}$ & $\begin{array}{l}\text { Number of } \\
\text { household } \\
\text { members }\end{array}$ & Oxen & $\begin{array}{l}\text { Herd size } \\
\text { (TLU) }\end{array}$ & $\begin{array}{l}\text { Draught } \\
\text { tools }^{\mathrm{a}}\end{array}$ & $\begin{array}{l}\text { Workers } \\
\text { ha }^{-1}\end{array}$ & $\begin{array}{l}\text { Oxen } \\
\mathrm{ha}^{-1}\end{array}$ & $\begin{array}{l}\text { TLU } \\
\mathrm{ha}^{-1}\end{array}$ & $\begin{array}{l}\text { TLU } \\
\text { worker }^{-1}\end{array}$ & $\begin{array}{l}\text { Tools } \\
\text { worker }^{-1}\end{array}$ \\
\hline \multirow[t]{6}{*}{1994} & $\begin{array}{l}\text { Low Resource Endowed } \\
\text { farms }\end{array}$ & LRE & 5 & $\begin{array}{c}3.8 \\
(2.1)\end{array}$ & $\begin{array}{c}3.0 \\
(1.0)\end{array}$ & $\begin{array}{c}5.0 \\
(1.6)\end{array}$ & $\begin{array}{c}0.8 \\
(1.1)\end{array}$ & $\begin{array}{c}1.5 \\
(0.8)\end{array}$ & $\begin{array}{c}1.2 \\
(1.1)\end{array}$ & $\begin{array}{c}1.0 \\
(0.5)\end{array}$ & $\begin{array}{c}0.2 \\
(0.2)\end{array}$ & $\begin{array}{c}0.4 \\
(0.3)\end{array}$ & $\begin{array}{c}0.5 \\
(0.3)\end{array}$ & $\begin{array}{c}0.4 \\
(0.4)\end{array}$ \\
\hline & Medium Resource & MRE & 15 & 9.1 & 6.1 & 11.2 & 2.9 & 7.1 & 4.2 & 0.7 & 0.3 & 0.8 & 1.3 & 0.8 \\
\hline & Endowed farms & & & $(2.3)$ & $(2.3)$ & $(4.1)$ & $(0.9)$ & $(3.4)$ & $(0.9)$ & $(0.2)$ & $(0.1)$ & $(0.4)$ & $(0.9)$ & $(0.3)$ \\
\hline & $\begin{array}{l}\text { High Resource Endowed } \\
\text { farms }\end{array}$ & HRE & 7 & $\begin{array}{l}15.8 \\
(3.7)\end{array}$ & $\begin{array}{l}14.4 \\
(4.1)\end{array}$ & $\begin{array}{l}25.9 \\
(7.4)\end{array}$ & $\begin{array}{c}4.7 \\
(0.8)\end{array}$ & $\begin{array}{l}12.2 \\
(5.0)\end{array}$ & $\begin{array}{c}5.3 \\
(0.8)\end{array}$ & $\begin{array}{c}0.9 \\
(0.1)\end{array}$ & $\begin{array}{c}0.3 \\
(0.1)\end{array}$ & $\begin{array}{c}0.8 \\
(0.2)\end{array}$ & $\begin{array}{c}0.8 \\
(0.3)\end{array}$ & $\begin{array}{c}0.4 \\
(0.1)\end{array}$ \\
\hline & $\begin{array}{l}\text { High Resource Endowed } \\
\text { farms with Large Herds }\end{array}$ & HRE-LH & 3 & $\begin{array}{l}19.8 \\
(6.4)\end{array}$ & $\begin{array}{l}13.8 \\
(5.0)\end{array}$ & $\begin{array}{c}26.7 \\
(11.0)\end{array}$ & $\begin{array}{c}7.3 \\
(3.1)\end{array}$ & $\begin{array}{c}52.6 \\
(24.5)\end{array}$ & $\begin{array}{c}7.0 \\
(1.0)\end{array}$ & $\begin{array}{c}0.7 \\
(0.0)\end{array}$ & $\begin{array}{c}0.4 \\
(0.1)\end{array}$ & $\begin{array}{c}3.1 \\
(2.5)\end{array}$ & $\begin{array}{c}4.6 \\
(3.7)\end{array}$ & $\begin{array}{c}0.5 \\
(0.1)\end{array}$ \\
\hline & Average & & 30 & $\begin{array}{l}10.9 \\
(5.8)\end{array}$ & $\begin{array}{c}8.3 \\
(5.2)\end{array}$ & $\begin{array}{l}15.1 \\
(9.8)\end{array}$ & $\begin{array}{c}3.4 \\
(2.2)\end{array}$ & $\begin{array}{c}11.9 \\
(15.9)\end{array}$ & $\begin{array}{c}4.2 \\
(1.9)\end{array}$ & $\begin{array}{c}0.8 \\
(0.3)\end{array}$ & $\begin{array}{c}0.3 \\
(0.1)\end{array}$ & $\begin{array}{c}1.0 \\
(1.0)\end{array}$ & $\begin{array}{c}1.4 \\
(1.6)\end{array}$ & $\begin{array}{c}0.6 \\
(0.3)\end{array}$ \\
\hline \multirow[t]{5}{*}{2010} & $\begin{array}{l}\text { Low Resource Endowed } \\
\text { farms }\end{array}$ & LRE & 7 & $\begin{array}{c}3.2 \\
(2.0)\end{array}$ & $\begin{array}{c}5.0 \\
(3.0)\end{array}$ & $\begin{array}{c}7.9 \\
(4.9)\end{array}$ & $\begin{array}{c}1.3 \\
(1.0)\end{array}$ & $\begin{array}{c}1.7 \\
(0.9)\end{array}$ & $\begin{array}{c}1.1 \\
(1.5)\end{array}$ & $\begin{array}{c}1.8 \\
(1.1)\end{array}$ & $\begin{array}{c}0.6 \\
(0.7)\end{array}$ & $\begin{array}{c}0.9 \\
(1.1)\end{array}$ & $\begin{array}{c}0.7 \\
(1.0)\end{array}$ & $\begin{array}{c}0.3 \\
(0.4)\end{array}$ \\
\hline & $\begin{array}{l}\text { Medium Resource } \\
\text { Endowed farms }\end{array}$ & MRE & 9 & $\begin{array}{c}7.5 \\
(2.4)\end{array}$ & $\begin{array}{c}7.3 \\
(1.6)\end{array}$ & $\begin{array}{l}12.6 \\
(1.7)\end{array}$ & $\begin{array}{c}4.1 \\
(6.5)\end{array}$ & $\begin{array}{c}6.2 \\
(4.7)\end{array}$ & $\begin{array}{c}5.3 \\
(2.9)\end{array}$ & $\begin{array}{c}1.1 \\
(0.5)\end{array}$ & $\begin{array}{c}0.6 \\
(1.0)\end{array}$ & $\begin{array}{c}0.9 \\
(0.6)\end{array}$ & $\begin{array}{c}0.8 \\
(0.6)\end{array}$ & $\begin{array}{c}0.8 \\
(0.6)\end{array}$ \\
\hline & $\begin{array}{l}\text { High Resource Endowed } \\
\text { farms }\end{array}$ & HRE & 11 & $\begin{array}{l}11.8 \\
(6.0)\end{array}$ & $\begin{array}{l}17.5 \\
(4.8)\end{array}$ & $\begin{array}{l}27.3 \\
(6.6)\end{array}$ & $\begin{array}{c}2.7 \\
(1.6)\end{array}$ & $\begin{array}{c}8.4 \\
(6.1)\end{array}$ & $\begin{array}{c}4.2 \\
(2.9)\end{array}$ & $\begin{array}{c}1.7 \\
(0.7)\end{array}$ & $\begin{array}{c}0.2 \\
(0.1)\end{array}$ & $\begin{array}{c}0.7 \\
(0.5)\end{array}$ & $\begin{array}{c}0.5 \\
(0.3)\end{array}$ & $\begin{array}{c}0.3 \\
(0.2)\end{array}$ \\
\hline & $\begin{array}{l}\text { High Resource Endowed } \\
\text { farms with Large Herds }\end{array}$ & HRE-LH & 3 & $\begin{array}{l}16.6 \\
(8.3)\end{array}$ & $\begin{array}{c}28.3 \\
(15.6)\end{array}$ & $\begin{array}{c}45.3 \\
(18.0)\end{array}$ & $\begin{array}{c}5.7 \\
(1.5)\end{array}$ & $\begin{array}{l}46.1 \\
(8.6)\end{array}$ & $\begin{array}{c}4.3 \\
(4.5)\end{array}$ & $\begin{array}{l}1.7 \\
(0.2)\end{array}$ & $\begin{array}{c}0.4 \\
(0.1)\end{array}$ & $\begin{array}{c}3.2 \\
(1.3)\end{array}$ & $\begin{array}{l}1.9 \\
(0.7)\end{array}$ & $\begin{array}{c}0.2 \\
(0.1)\end{array}$ \\
\hline & Average & & 30 & $\begin{array}{c}9.0 \\
(6.1)\end{array}$ & $\begin{array}{l}12.6 \\
(9.2)\end{array}$ & $\begin{array}{c}20.1 \\
(13.5)\end{array}$ & $\begin{array}{c}3.1 \\
(3.8)\end{array}$ & $\begin{array}{c}9.9 \\
(13.5)\end{array}$ & $\begin{array}{c}3.8 \\
(3.1)\end{array}$ & $\begin{array}{c}1.5 \\
(0.8)\end{array}$ & $\begin{array}{c}0.4 \\
(0.6)\end{array}$ & $\begin{array}{c}1 \\
(1.0)\end{array}$ & $\begin{array}{c}0.8 \\
(0.7)\end{array}$ & $\begin{array}{c}0.4 \\
(0.5)\end{array}$ \\
\hline
\end{tabular}

\footnotetext{
a Ploughs, weeders and sowing machines.
}

fewer farms 'fell down' during the unfavourable period than in the previous period.

Analysis of specific farms allowed us to better understand the various trajectories for a given farm type. We found evidence that HRE farms and LRE farms had 'stepped up' to a more productive farm type by increasing their herd size (Fig. 4a, b). Some MRE farms 'fell down' due to a decrease in available livestock for traction (decreased oxen worker $^{-1}$ ) (Fig. 4c) and one HRE farm 'fell down' due to a decrease in total cropped land, number of workers, number of oxen and herd size (Fig. 4d). Other farms remained 'hanging in' the same farm type (Fig. 4a, b, c).

\subsection{Farm trajectories: change in land and labour productivity}

For MRE, HRE and HRE-LH farms, average nitrogen and phosphorus use intensity increased from 1994 to 2004 (Fig. 5), along with an increase in the share of maize in the total cropped land (Fig. 6). During the following cotton crisis, the share of cotton decreased (Fig. 6), explaining the downward trend in mineral fertilizer application rates (Fig. 5). This illustrates the fact that farmers rely on the cotton sector for credit to purchase fertilizer. On the other hand, organic fertilizer use intensity significantly increased over the entire monitoring period for MRE and HRE-LH farms $\left(\mathrm{P}<0.01, \mathrm{R}^{2}=0.47\right.$ and 0.45 respectively $)$ (Fig. 5c).

We found no significant change in crop yield over time for any farm type and any crop. However, maize yields have decreased since the period when CMDT collapsed (Fig. 7). Crop yields of LRE farms were more variable, especially for maize ( $\mathrm{CV}=72 \%$ ), compared with the other farm types. For MRE, HRE and HRE-LH farms, cotton and maize yields fluctuated more than sorghum and millet yields (Fig. 7). Labour productivity for both cotton and cereals drastically decreased since the beginning of the unfavourable period when CMDT collapsed (Fig. 8) as a

Table 2

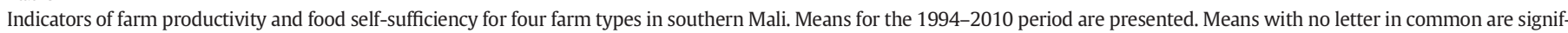
icantly different.

\begin{tabular}{|c|c|c|c|c|}
\hline & $\begin{array}{l}\text { Low Resource Endowed } \\
\text { (LRE) farms }\end{array}$ & $\begin{array}{l}\text { Medium Resource Endowed } \\
\text { (MRE) farms }\end{array}$ & $\begin{array}{l}\text { High Resource Endowed } \\
\text { (HRE) farms }\end{array}$ & $\begin{array}{l}\text { High Resource Endowed farms } \\
\text { with Large Herds (HRE-LH) }\end{array}$ \\
\hline$\%$ of farms growing cotton & $35 b$ & $94 a$ & $96 a$ & $99 a$ \\
\hline$\%$ of farms growing maize & $33 b$ & $88 a$ & $88 a$ & $85 a$ \\
\hline$\%$ cotton in total cropped land & $10 c$ & $34 b$ & $32 b$ & $39 a$ \\
\hline$\%$ of maize in total cropped land & $5 b$ & $9 a$ & $9 a$ & $10 a$ \\
\hline Oxen worker ${ }^{-1}$ & $0.1 d$ & $0.5 a$ & $0.3 c$ & $0.4 b$ \\
\hline \multicolumn{5}{|l|}{ Input use intensity $\left(\mathrm{kg} \mathrm{ha}^{-1}\right.$ year-1) } \\
\hline Nitrogen & $7 c$ & $21 a$ & $19 b$ & $20 a b$ \\
\hline Phosphorus & $2 b$ & $5 a$ & $5 a$ & $5 \mathrm{a}$ \\
\hline Organic fertilizer & $521 d$ & $1872 b$ & $1551 c$ & $2614 a$ \\
\hline \multicolumn{5}{|l|}{ Land productivity $\left(\mathrm{kg} \mathrm{ha}^{-1}\right.$ year $\left.{ }^{-1}\right)$} \\
\hline Cotton & $754 b$ & $912 a$ & $944 a$ & $1051 a$ \\
\hline Maize & $1298 c$ & $1888 b$ & $2081 a b$ & 2427 a \\
\hline Sorghum & $650 c$ & $907 b$ & $871 b$ & $1107 a$ \\
\hline Millet & $524 c$ & $697 b$ & $668 b$ & $884 a$ \\
\hline \multicolumn{5}{|l|}{ Labour productivity ( $\mathrm{kg}$ worker $^{-1}$ year $^{-1}$ ) } \\
\hline Cotton & $234 b$ & $490 a$ & $285 b$ & $427 a$ \\
\hline All cereals & $626 b c$ & $852 a$ & $567 c$ & $682 b$ \\
\hline Maize & $143 b$ & $243 a$ & $179 a b$ & $241 a$ \\
\hline Sorghum and millet & $510 a b$ & $571 a$ & $364 c$ & $440 \mathrm{~b}$ \\
\hline Grain/capita (kg person ${ }^{-1}$ year $^{-1}$ ) & $455 \mathrm{ab}$ & $493 \mathrm{a}$ & $327 \mathrm{c}$ & 379 bc \\
\hline$\%$ fulfillment of household calorific need & $164 b$ & $195 a$ & $132 c$ & $154 b c$ \\
\hline
\end{tabular}



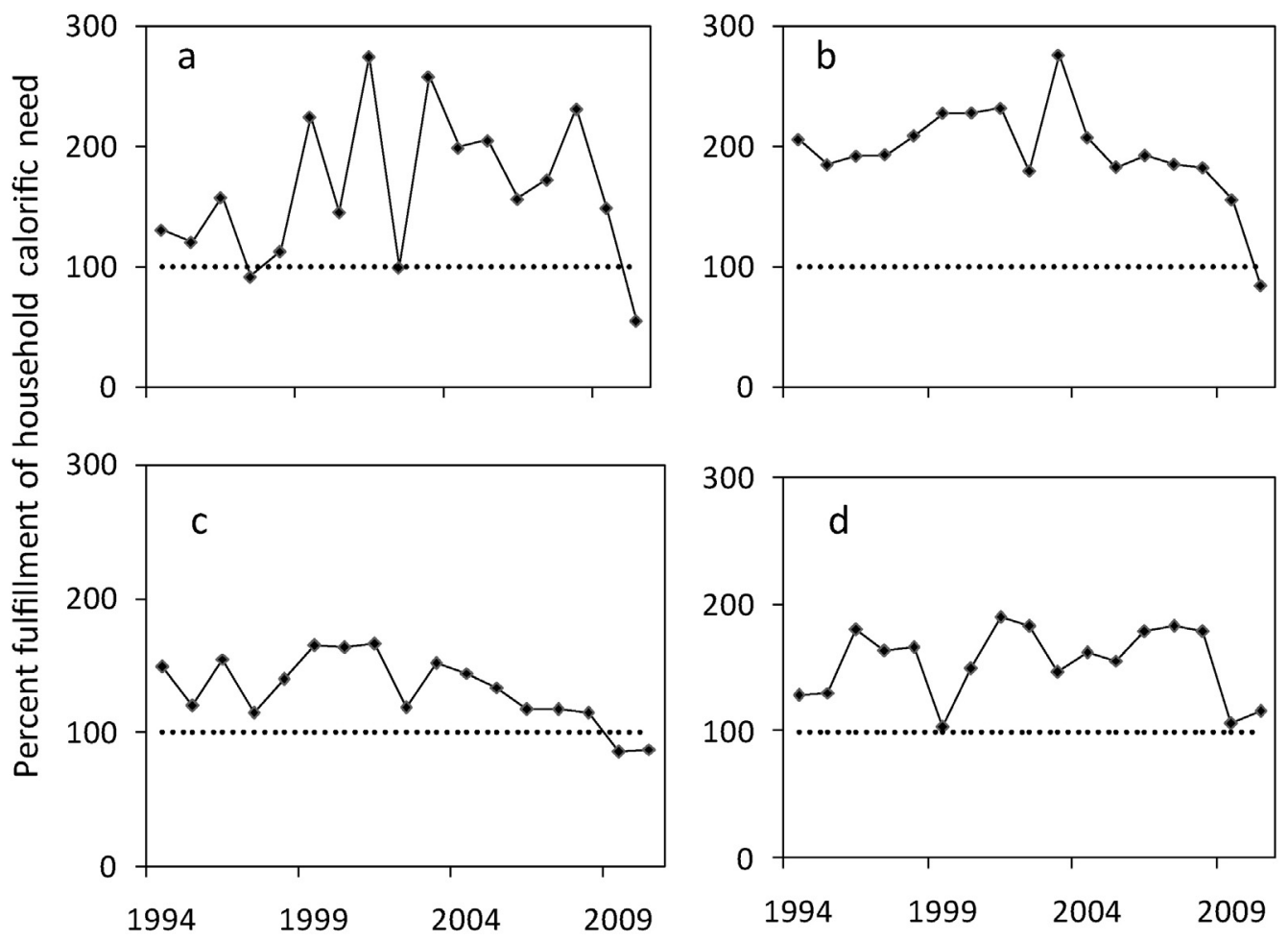

Year

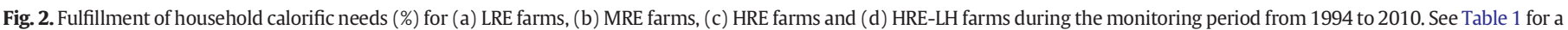
description of the main characteristics of the farm types.

result of stagnating yields and increased number of workers per farm (Table 1).

\subsection{Focus group discussion with farmers}

During the focus group discussion, all farmers recognized themselves in the typology, and mentioned to which type they belong. The presentation of the different trajectories: 'stepping up', 'falling down' or 'hanging in' led to fruitful debates, adding insight in the different trajectories. Farmer explanations for the trajectories were mostly related to intra-household organization, fodder production, off-farm opportunities and sharing of income.

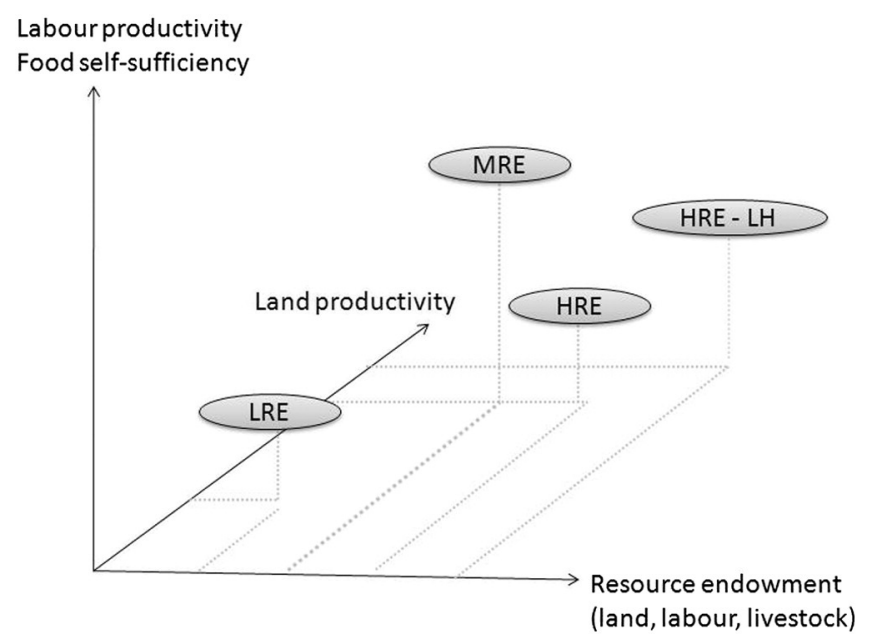

Fig. 3. Conceptual representation of four farm types in a three-dimensional space of resource endowment, land productivity and combined labour productivity and food self-sufficiency. See Table 1 for a description of the main characteristics of the farm types.

\section{Discussion}

\subsection{Discussion of the method for understanding farm trajectories}

Studies using static typologies and assessing change over time by a new farm typology each year (Iraizoz et al., 2007; Mignolet et al., 2007; Sanogo et al., 2010) may confound trajectories and change in farm type definition. Our study builds on the body of evidence that fixed thresholds need to be defined, ensuring invariability in the definition of types and relevance of the trajectories depicted (Chopin et al., 2014).

The determined cut-off values allowed an easy classification of the farm and determination of their trajectories. When there was no overlap between two resource endowment variables, we arbitrarily defined the cut-off as the maximum of the variable with the lowest median. One could also have taken the minimum of the variable with the highest median or the average of the maximum and the minimum (see Supplementary materials, Fig. 4). A sensitivity analysis showed that changing the cut-off determination method led to a marginal change in land and labour productivity of the different types (see Supplementary materials, Table 2) and to slight changes in the quantification of trajectories (see Supplementary materials, Table 3). Therefore, the latter need to be interpreted cautiously. However, as the same cut-offs were used throughout the monitoring period, the relative quantification of trajectories between periods can be interpreted with confidence. In other datasets, if all variables overlap, an interpretative value resulting in the least overlap can be chosen or classification and regression tree (CART) analysis may be used (Chopin et al., 2014).

Mushongah and Scoones (2012) and Valbuena et al. (2014) similarly described a rich diversity of individual storylines and conceptualized possible trajectories in link with socio-economic drivers. Their studies were based on two snapshots at the beginning and the end of a ten and twenty year period respectively. This type of longitudinal study does not allow tracing back non-linearity in trends. For example, in our study the year-to-year monitoring indicated that fertilizer use 
Table 3

Importance of different farm trajectories for distinct periods according to the context of the cotton market.

\begin{tabular}{|c|c|c|c|c|c|c|c|}
\hline \multirow[t]{2}{*}{ Period } & & \multicolumn{6}{|l|}{$\%$ of farms } \\
\hline & & $\begin{array}{l}\text { (a) 'hanging in' with high land } \\
\text { and labour productivity }\end{array}$ & (b) 'stepping up'b & $(a)+(b)$ & $\begin{array}{l}\text { (c) 'hanging in' with low land } \\
\text { and labour productivity }\end{array}$ & $\begin{array}{l}\text { (d) 'falling } \\
\text { down'd }\end{array}$ & $(\mathrm{c})+(\mathrm{d})$ \\
\hline \multirow[t]{2}{*}{ Period 1: Favourable context } & 1994-1999 & 47 & 7 & 54 & 33 & 13 & 46 \\
\hline & 1999-2004 & 43 & 10 & 53 & 37 & 10 & 47 \\
\hline $\begin{array}{l}\text { Period 2: Unfavourable period when } \\
\text { CMDT support collapsed }\end{array}$ & 2004-2009 & 47 & 17 & 63 & 27 & 10 & 37 \\
\hline Whole period & 1994-2009 & 47 & 17 & 64 & 23 & 13 & 36 \\
\hline
\end{tabular}

a 'Hanging in' with high productivity = farms that stayed in MRE or HRE-LH.

b 'Stepping up' = farms that transitioned from HRE to HRE-LH, or from LRE to MRE, or from HRE to MRE.

c 'Hanging in' with low productivity = farms that stayed in HRE or LRE.

d 'Falling down' = farms that transitioned from MRE to HRE, or from HRE to LRE, or from HRE-LH to HRE.

intensity increased from 1994 to 2004 and decreased thereafter, a trend that would not have been revealed if only the start year 1994 and the end year 2010 had been considered. The year-to-year monitoring also allowed for a detailed analysis of inter-year food self-sufficiency variability, and therefore the risk of food insufficiency. Furthermore, the trajectories we described are clearly linked to easy-to-identify farm types (see Supplementary materials, Fig. 5), making it easy to scale up recommendations in the Koutiala district.

\subsection{Resource endowment and farm trajectories}

Our study provides a comprehensive picture of farm trajectories over two decades in the Koutiala district. 17\% of the farms 'stepped up' to a type of higher land and labour productivity and food selfsufficiency status while $70 \%$ of the farms remained 'hanging in', and only $13 \%$ of the farms 'fell down' (Table 3 ). Hence the majority of farm households have been able to avoid falling down, notwithstanding a decrease in the available fodder resources (Van Keulen and Breman, 1990) and the unfavourable economic-institutional context during the period when support from CMDT collapsed. Farmers have been able to do so by transhumance, conducting off-farm work (Abdulai and CroleRees, 2001) and increasing the number of traction animals (Table 1). Even though the use of mineral fertilizer and organic materials did not increase for all types, farmers have been able to counteract soil fertility decline to some extent thanks to these practices (Benjaminsen et al., 2010; de Ridder et al., 2004).

However, for $70 \%$ of the farms, which remained 'hanging in', neither has land productivity nor food self-sufficiency improved over the last two decades (Figs. 2 and 7). Indeed, labour productivity decreased since the beginning of the unfavourable period when support from CMDT collapsed (Fig. 8). This lack of productivity improvement is in line with stagnating crop yields in many countries of sub-Saharan Africa (Tittonell and Giller, 2013). Decreasing labour productivity suggests that farming is less able to meet the needs of a rapidly growing population. Farms already fail to achieve food self-sufficiency in some years and this may increase in frequency if crop yields do not improve. The decrease in cotton area initiated in 2004 for MRE, HRE and HRE-LH (see Fig. 6) was compensated by a significant increase in average cereals
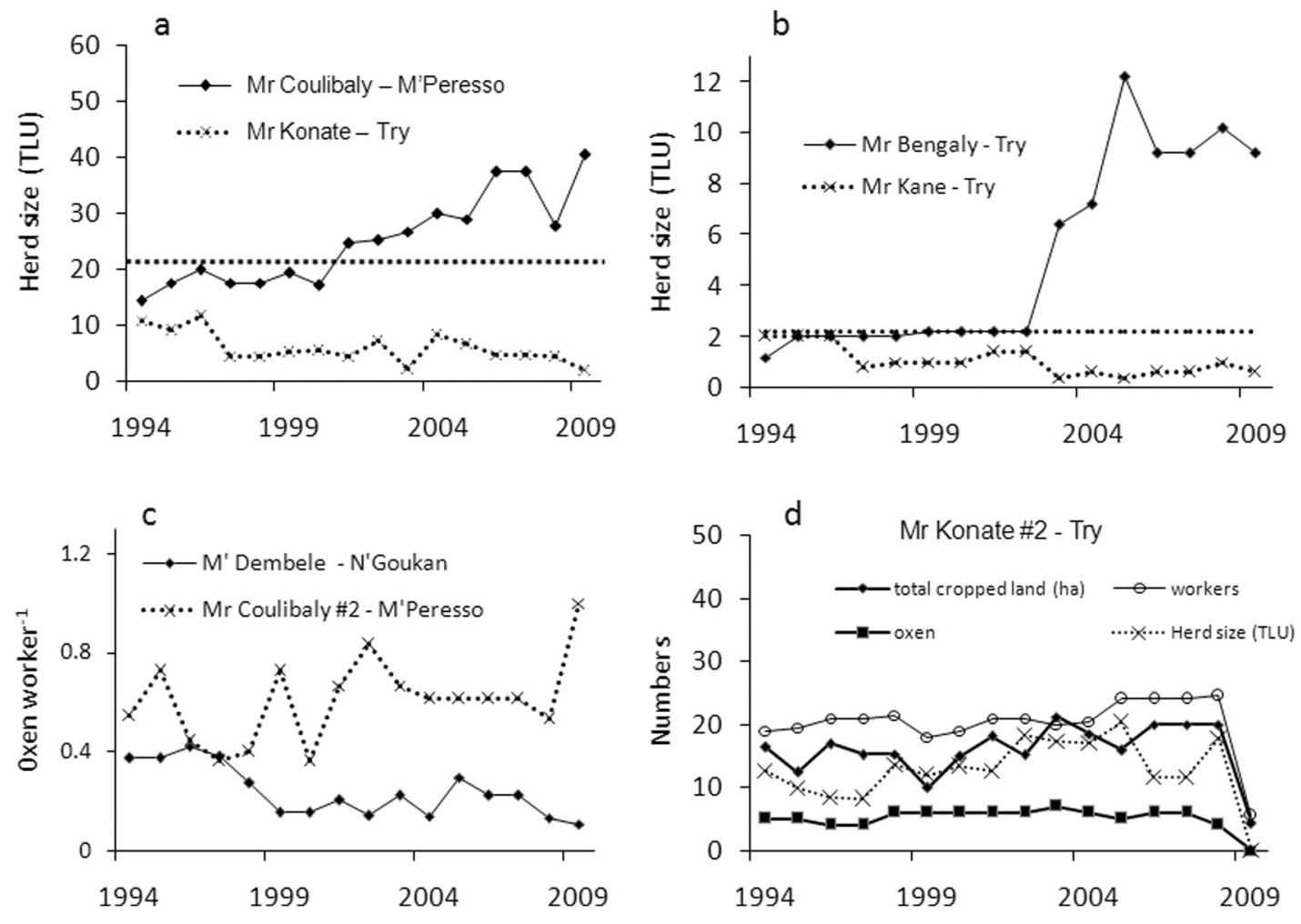

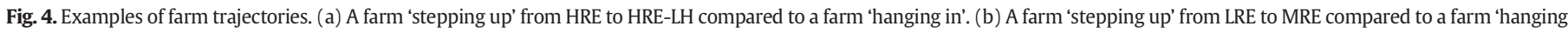

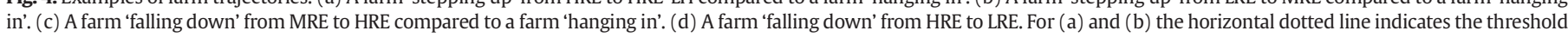
herd size that discriminates two farm types. Names of household heads are fictitious. See Table 1 for a description of the main characteristics of the farm types. 

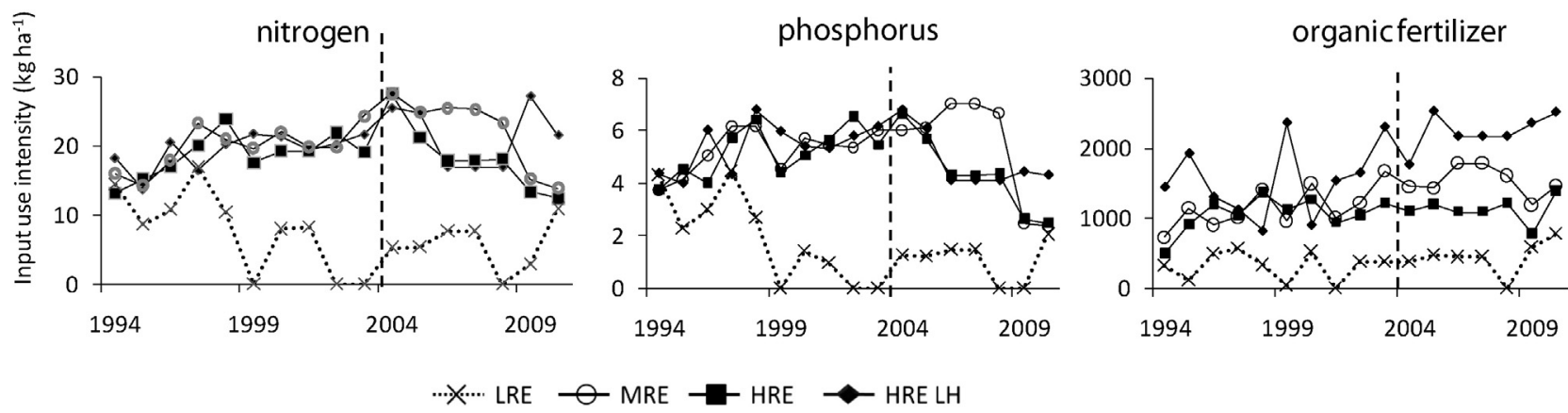

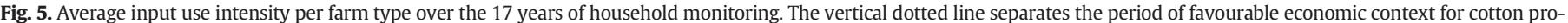

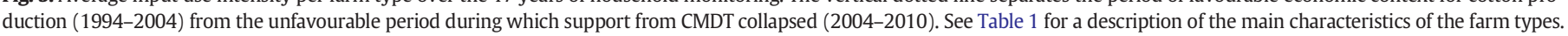

share (maize, sorghum and millet) since 2004 for MRE, HRE and HRE-LH $(\mathrm{P}<0.05, \mathrm{R}-\mathrm{sq}=0.66,0.87$ and 0.86 respectively, data not shown $)$. Therefore although cereal yields did not increase, total cereal production was able to cope with increase in population, thanks to the increase of cereal share in the total cropped land.

Our study confirmed the strong relationship between resource endowment and land productivity (Table 2), which was described earlier (Djouara et al., 2005). During the monitoring period only 35\% of LRE farms grew cotton, which provided access to credit for mineral fertilizers through the CMDT. LRE farms applied on average only $7 \mathrm{~kg}$ of $\mathrm{N} \mathrm{ha}^{-1}$ and $1 \mathrm{~kg}$ of $\mathrm{P} \mathrm{ha}^{-1}$. With very small livestock herds and seldom a cart to transport organic fertilizer, LRE farms used on average only $0.56 \mathrm{t} \mathrm{DM} \mathrm{ha}^{-1}$ organic fertilizer across the farm. LRE farms also did not have access to a complete oxen span, which negatively impacted their ability to sow and weed in a timely fashion, impairing yields. With smaller cotton yields ( $750 \mathrm{~kg} \mathrm{ha}^{-1}$ ) on small areas the LRE farms struggle to pay back credit for fertilizers, consequently losing the possibility for future contracts from the CMDT. This risk discouraged LRE farmers from growing cotton, explaining the rapid decline in the share of cotton in their cropped land (Fig. 6a). On the other hand, MRE farms obtained better cotton $\left(910 \mathrm{~kg} \mathrm{ha}^{-1}\right)$ and maize $\left(1300 \mathrm{~kg} \mathrm{ha}^{-1}\right)$ yields due to more mineral fertilizer inputs ( $20 \mathrm{~kg} \mathrm{~N} \mathrm{ha}^{-1}$ and $5 \mathrm{~kg} \mathrm{P} \mathrm{ha}^{-1}$ ), financed through credit from cotton cultivation, and a small herd and a cart to handle organic fertilizer. Yields of sorghum and millet were also 40 and 33\% larger on MRE than LRE farms (Table 2), thanks to the positive residual effect of fertilizer applied to cotton and maize earlier in the rotation. This crucial role of cotton for soil fertility maintenance and improved food crop productivity was described in another study (Ripoche et al., 2015). HRE farms achieved similar land productivity as MRE farms, because of their similar mineral and organic fertilizer inputs. The greatest land productivity for all crops was obtained by HRE-LH farms (exceeding $1000 \mathrm{~kg} \mathrm{ha}^{-1}$ for cotton and sorghum and $2400 \mathrm{~kg} \mathrm{ha}^{-1}$ for maize), explained by the largest rates of organic manure inputs allowed by the largest animal to land ratio of all farm types (Table 1). In addition, our study clarified the more complex link between resource endowment, labour productivity and food self-sufficiency (Table 2 and Fig. 2). Some 'large farms' achieved larger crop yields, and yet had poor labour productivity and food self-sufficiency (see HRE farms). The
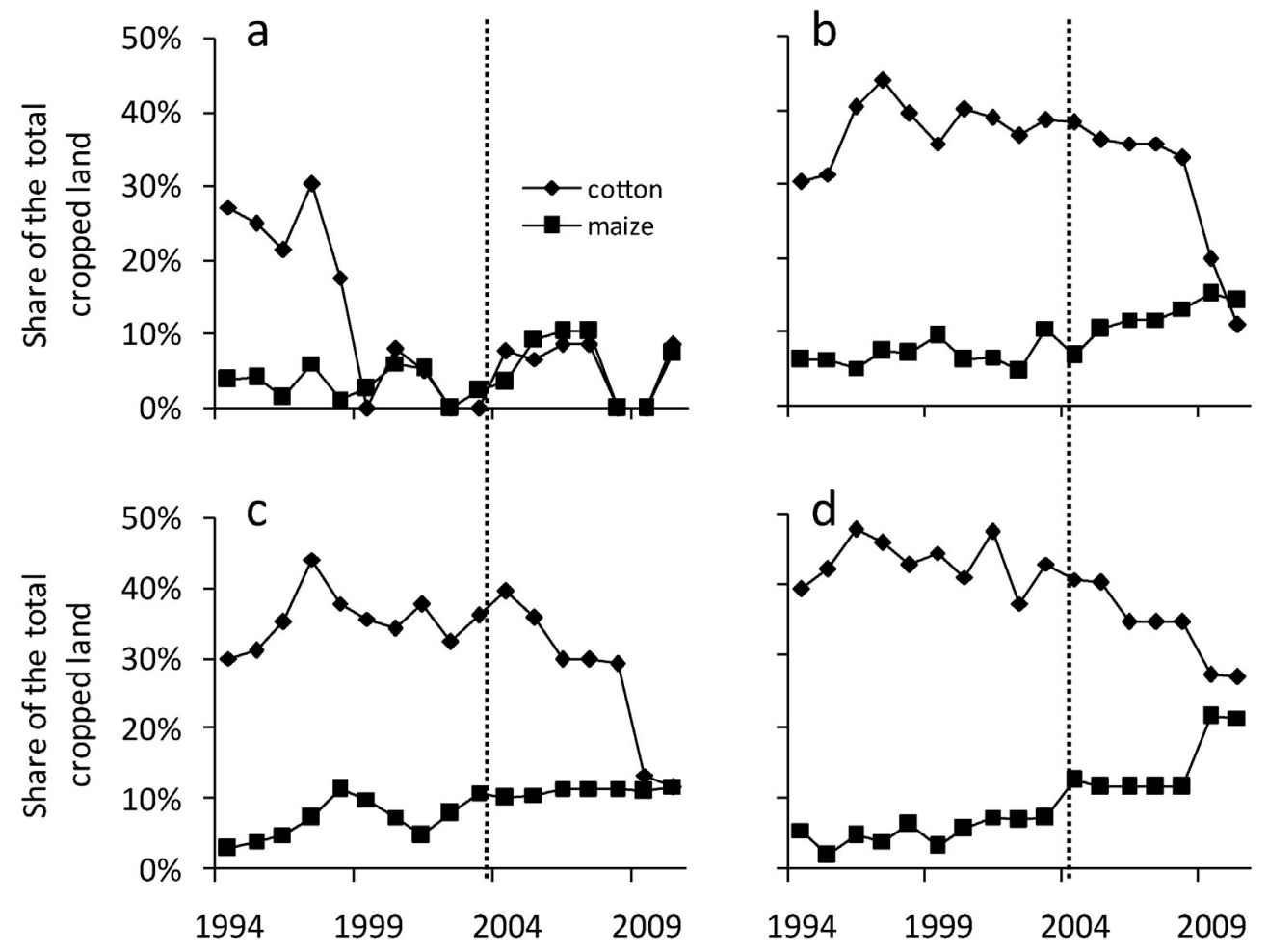

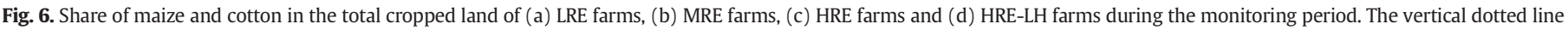

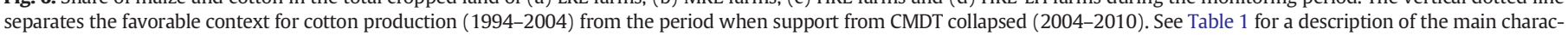
teristics of the farm types. 


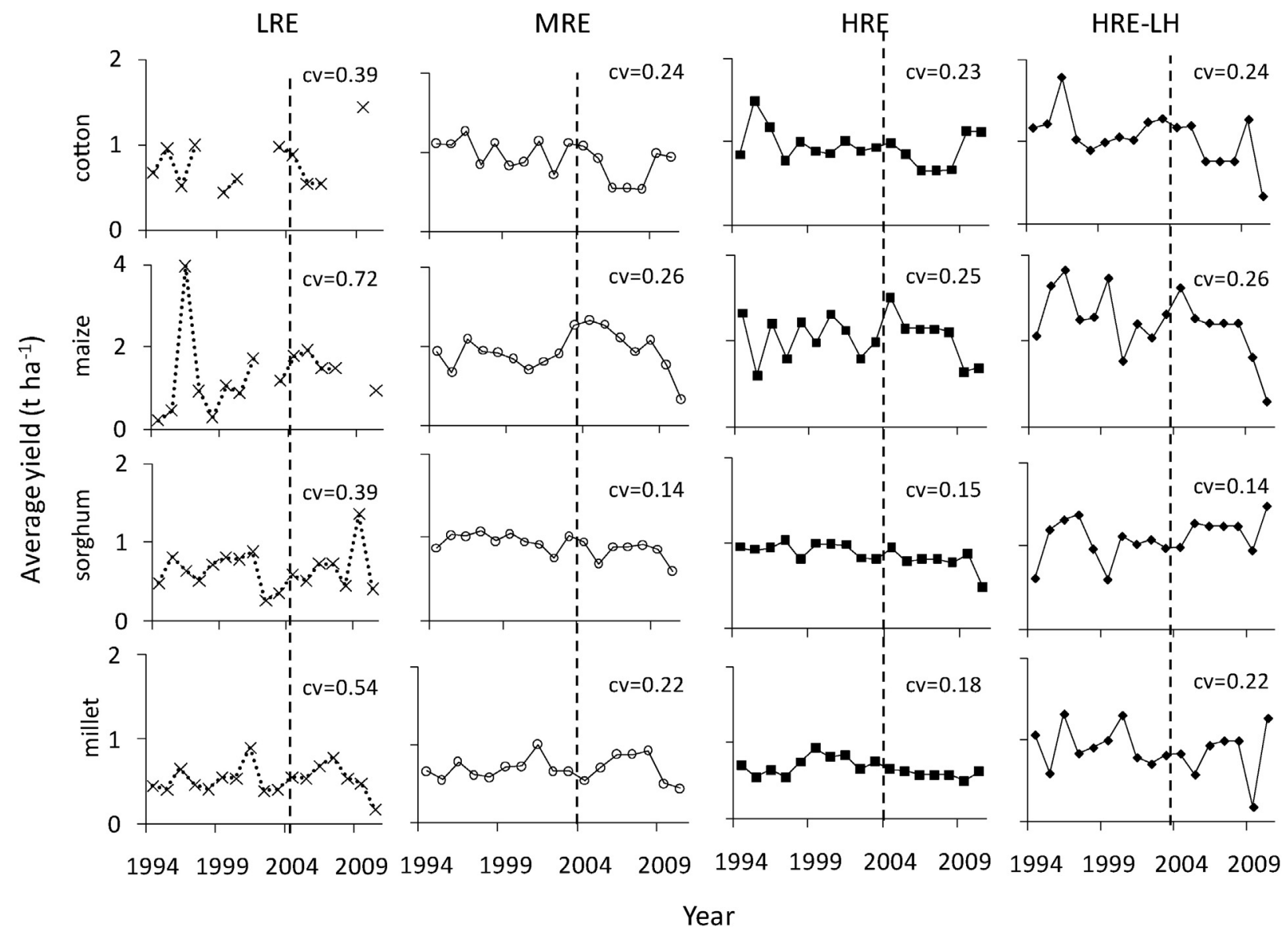

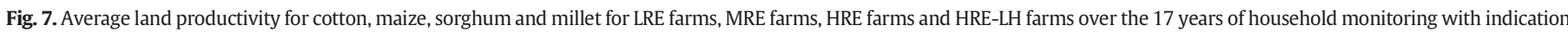

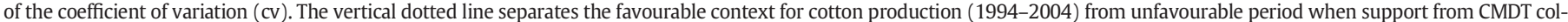
lapsed (2004-2010). In some years, LRE did not grow cotton and/or maize. See Table 1 for a description of the main characteristics of the farm types.

expected correlation between larger farm size (more family members, land and labour) and betterment of the household situation (Fig. 9a), concealed a 'falling down' trajectory in which the labour productivity and food self-sufficiency declined as the farm increases in size (Fig. 9b).

\subsection{Farm trajectories illustrated by farmers' reality}

The 'stepping up' trajectories recorded illustrate the scope for improving farm performance in the area. For example, Mr Coulibaly in
M'Peresso ‘stepped up' from HRE to HRE-LH in 2001 as a result of enlarging his herd size, compared with Mr Konate in Try who did not increase his herd size and remained in the HRE type (Fig. 4a). During focus group discussions, farmers indicated that increasing the herd size depends on a good intra-household work organization for crop and livestock activities. Livestock feeding and watering are timeconsuming activities, for which labour is often lacking, as the household members are primarily occupied with cropping activities. As a result, when these activities are handed over to an unmotivated child, they
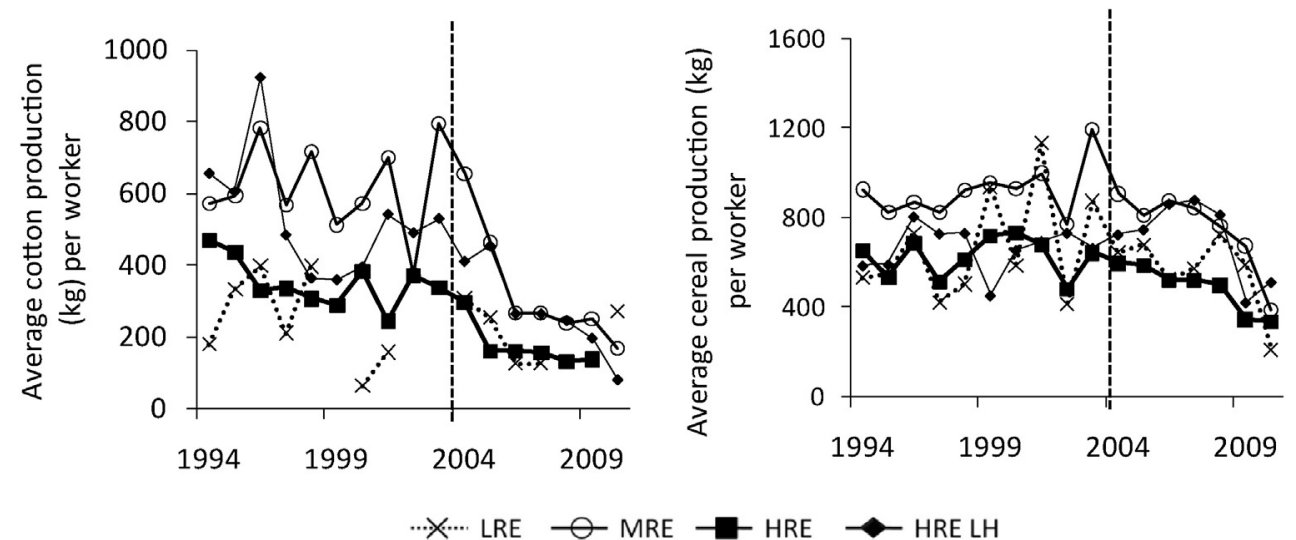

HRE LH

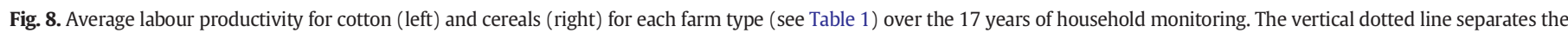
favourable context for cotton production (1994-2004) from the period when support from CMDT collapsed (2004-2010). 

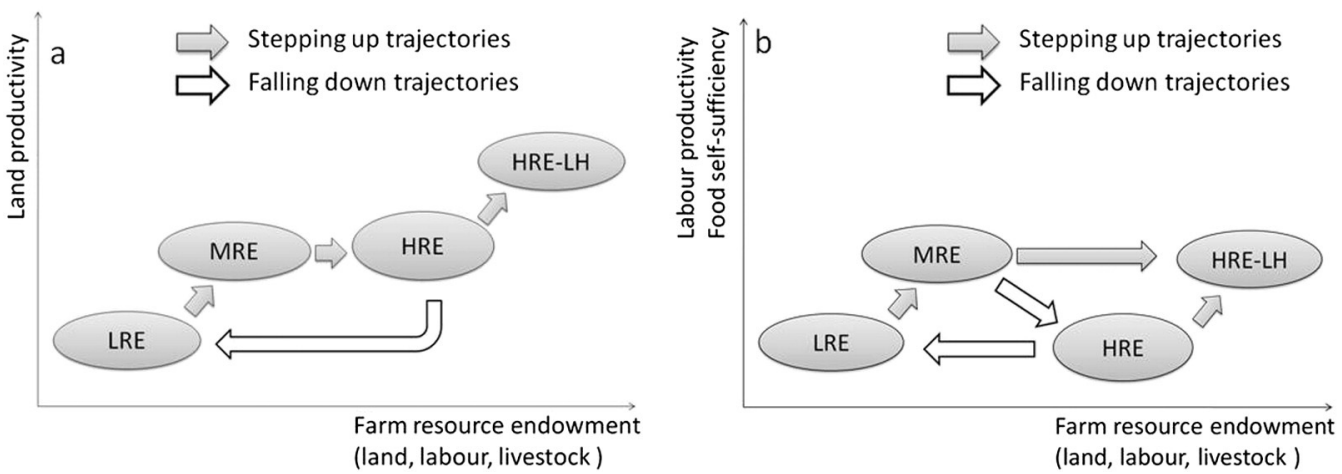

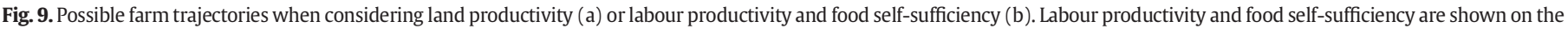
same axis as they follow the same behaviour.

are not carried out properly, thus compromising the animal health status and herd growth. Fodder production, e.g. cowpea, was mentioned as another strategy for increasing the herd size. Also low resource endowed farmers, like Mr Bengaly from Try, can step up to a more productive farm type by increasing herd size (Fig. 4b). As indicated by the farmers, LRE farms are small farms with little cotton production and cash income from crop cultivation, so that a step up is possible only through the investment of income gained off-farm into the farm. Farmers indicated that seasonal migration of young people to gold mines can offer the cash needed for such farm investments (cf. Pijpers, 2014).

Some farms fell down during the monitoring period. For example, the number of workers in Mr Dembele's farm in N'Goukan doubled, leading to a decrease in the oxen worker ${ }^{-1}$ ratio (Fig. 4c). The increasing number of workers is a natural development in the typical Malian extended families characterized by polygamy and high birth rates (with 45 births per 1000 people, Mali is the third country in the world according to the Index Mundi Data portal, http://www.indexmundi. com $/ \mathrm{g} / \mathrm{r} \cdot \mathrm{aspx}$ ? $\mathrm{v}=25$, last accessed 03/06/2015). While Mr Dembele transitioned from MRE to HRE, his land productivity remained equal, thus decreasing labour productivity and food self-sufficiency, which is interpreted as 'falling down' (Fig. 9b). 'Falling down' trajectories also involve farms moving from HRE to LRE, like Mr Konate \#2 from Try in 2009 (Fig. 4d). Farmers explained this trajectory by a household split because of a disagreement among household members over income sharing from cotton. In the typical Malian extended family, the head of the household is in charge of the share of the income obtained from cotton production among the younger brothers and/or married sons. In some cases, an inequitable share of this income can lead to tensions between members of the household and lead to the split of the household. Our analysis showed that only $13 \%$ of the 30 farms followed 'falling down trajectories', and that those were not influenced by the unfavourable period when support from CMDT collapsed (Table 3). However, due to the shorter monitoring period of the 'unfavourable context' (2004-2009) as compared with the 'favourable context' (1994-2004), effects of the cotton crisis might still be observed in the future if the uncertainties concerning cotton production persist.

For some farms, "hanging in" masked transitions up and down at various times during the monitoring period. For example, Mr Kane \#2 in Try, remained a HRE farm, but with strong fluctuations in the herd size, illustrating a common trend in West African livestock keeping: farmers use livestock as a hedge against risk, decapitalizing to get the cash needed to face an unexpected event (Supplementary materials, Fig. 6a). Mr Coulibaly \#3 in M'Peresso is a MRE farm with oscillating worker numbers, as explained by the dynamics of the young people entering and leaving the farm (Supplementary materials, Fig. 6b) as a result of rural migration (Hertrich and Lesclingand, 2013).

\subsection{Two decades, a change in farm practices?}

Mineral fertilizer use has decreased since the beginning of the cotton crisis in 2004 (Fig. 5). This decrease was linked to a change in cropping patterns: a decrease in the share of cotton in the total cropped land since 2004, which was not offset by an increase in the share of maize (Fig. 6). This highlights the crucial role of the parastatal company CMDT with respect to agricultural input supply in Mali. There is a strong need for increased input use to underpin crop yield improvement. The CMDT is the only institution that guarantees access to fertilizer for cotton and maize. The decision to split CMDT in four local units owned by private societies, together with the creation of one national union of farmer cooperatives in 2007 to take over some of the organization of the value-chain (access to credit, capacity building and information of producers, market share), raises some uncertainties on the future of the cotton sector (Bélières et al., 2008). So far the privatization has not been operationalized, and the challenge of regaining farmers' trust in cotton production remains. Another remaining challenge is farmer empowerment in the price negotiation process (Nubukpo, 2011). However, the recent investment in fertilizer subsidy of Malian state for rice, cotton and maize, raising from 13.4 billion CFA in 2008 to 21.2 billion CFA in 2010 offers scope for an increase of fertilizer use intensity (Aparisi et al., 2013). Furthermore, farmer cooperatives working on cereal commercialization and providing credit for fertilizer also offer potential (Kaminski et al., 2013).

All of the farms with cattle (MRE, HRE, HRE-LH) used substantial amounts of organic manure with HRE-LH using $2.5 \mathrm{t} \mathrm{DM} \mathrm{ha}^{-1}$ on average across the farm in 2010 (Fig. 5). For a typical HRE-LH farm, Blanchard (2010) measured a lower organic fertilizer use intensity of $1.6 \mathrm{t} \mathrm{DM} \mathrm{ha}^{-1}$. Our database contains farmers' estimates of the number of cartloads, from which the amount of organic fertilizer was derived using a conversion of $200 \mathrm{~kg}$ per cartload and $70 \%$ of dry matter (Kanté, 2001). The larger amounts presented in this study might thus be related to farmers overestimating the number of cartloads or to an overestimate of the cartload weight. However, focusing on the trends and the relative differences, HRE-LH and MRE farm types increased their organic fertilizer use intensity by 74 and $100 \%$ respectively over the last two decades. Bodnar (2005) also found that organic fertilizer use intensity in Koutiala region went from 0.7 t DM ha $^{-1}$ in 1993 to $1.2 \mathrm{t} \mathrm{DM} \mathrm{ha}^{-1}$ in 2003; a $71 \%$ increase. This promising trend is the result of the efforts of the extension services in the district, who have been training farmers intensively to pen animals at night to collect animal droppings and to recycle more biomass by adding crop residues to cattle beds and digging composting pits (Blanchard, 2010). Considering an average nutrient content of $1.1 \% \mathrm{~N}$ and $0.2 \% \mathrm{P}$ (Bodnar, 2005), the organic fertilizer applied by HRE-LH farms ( $2.5 \mathrm{t} \mathrm{DM} \overline{h^{-1}}$ ), contained $28 \mathrm{~kg}$ of N and $5 \mathrm{~kg}$ of $\mathrm{P}$ per ha, which is similar to the $\mathrm{N}$ and $\mathrm{P}$ input rate from 
mineral fertilizer. In reality, farmers concentrate $80 \%$ of the organic fertilizer on cotton (data not shown), which in 2010 covered 5.6 ha on HRE-LH farms. This results in a nutrient input from manure of $65 \mathrm{~kg}$ of $\mathrm{N} \mathrm{ha}{ }^{-1}$ and $12 \mathrm{~kg}$ of $\mathrm{Pha}^{-1}$.

\subsection{Development pathways and options for sustainable intensification}

Enhancing productivity through sustainable intensification is essential for agricultural development. Interventions should improve the farming situation of farms 'hanging in' with low productivity. Credit for investment in farm equipment (oxen, ploughs) is the lever for 'stepping up' of LRE farms and improvement of HRE labour productivity. Increased oxen endowment improves the timeliness of sowing, which positively impacts cotton, maize and sorghum yields (Traore et al., 2014). The Asian example of credit systems financing one-quarter of farm equipment assets (Mellor, 2014) serves as an inspiration for facilitating the 'stepping up' of LRE farms. Nevertheless, we did not capture the complete livelihood strategies of households as data on off-farm activities were not available in the panel dataset. However existing literature shows that cash-oriented non-farm activities provide only $6 \%$ of total household income per capita in the Koutiala region (Abdulai and CroleRees, 2001), indicating that farming remains the major livelihood strategy for farms in the Koutiala region. Future analyses would also benefit from including information on livestock productivity (milk, meat consumption and animal sales) and inputs (purchased feed, veterinary care).

For HRE farms with relatively large cattle herds, improved livestock productivity through shorter calving intervals and increased calving rates for faster oxen turn-over can be achieved through better herd management, feeding practices and veterinary care (Sanogo, 2011).

For farms with large herds, land productivity can be improved by increasing manure availability and its nutrient cycling efficiency through proper collection and storage procedures (Rufino et al., 2007). Furthermore, with maize/legume intercropping, fodder can be produced with a small penalty to maize yields (Rusinamhodzi et al., 2012), hence providing opportunities to keep part of the cattle herd that would otherwise move in transhumance and benefit from its manure. The growing urban population increases the demand for dairy products (meat, milk) and processed cereals. This creates opportunities to intensify milk production through stable feeding of cows (Sanogo, 2011; Tarawali et al., 2002), or to intensify cereal production through improved varieties and increased organic and mineral fertilizers use. As MRE farms usually surpass food self-sufficiency, they can be net sellers of their cereal surpluses. Emerging farmer cooperatives are organizing the storage of cereal grains and facilitating contracts with buyers at local and national scales (Kaminski et al., 2013). Increasing off season productivity with irrigation is another option that can increase land and labour productivity, income, and food self-sufficiency (Pachpute, 2010). These farm type specific technical options must be discussed with the head of the household, but also with young people and women who participate in farming activities, to ensure the intra-household cohesion that was pointed out by farmers as a prerequisite to stepping-up trajectories.

To underpin those positive changes in agriculture, broader socioeconomic and politic change is needed. Subsidized imported products (meat, milk powder) compete with local products and artificially lower prices. International trade agreements give African states some leeway to raise their agricultural trade protection level and thus raise domestic prices (Laroche Dupraz and Postolle, 2013). Improved roads could also increase farm gate prices (Obare et al., 2003). Apart from intensification of agriculture, investment in family planning and the associated fertility reduction can also be an important means of responding to the increasing land constraints (Headey and Jayne, 2014).

\section{Conclusion}

Longitudinal studies of smallholder farming systems in Africa are rare but provide important insights that may help to guide future interventions for rural development. The study area, the Koutiala district, is representative of the 'cotton zone' of the Sudano-Sahel of West Africa where the income from cotton has allowed farmers to accumulate cattle (Dufumier and Bainville, 2006). Our study shows that this general impression of an increase in wealth and numbers of cattle in the Koutiala region masks a rich diversity of dynamics for different households. Over the two decades, $17 \%$ of the farms were able to achieve better land and labour productivity and more food self-sufficiency, but $70 \%$ remained in the same type and 13\% 'fell down' to a type with less land and labour productivity and less food self-sufficiency.

Nor have the underlying changes been unidirectional - the changing policy and economic environment have exerted a strong influence. Although changes in governmental support did not appear to impact farm trajectories, they strongly impacted the intensity of fertilizer use within each farm type. We found no change in crop yields over the two decades, and yet labour productivity decreased, a worrying trend given the increasing population.

The options available for farmers to achieve a 'sustainable intensification' of their farming systems are several. Farm equipment can still be increased; the cereal crops, maize, sorghum and millet, have emerged as cash crops (Kaminski et al., 2013); there are opportunities for intensification of milk production (Sanogo, 2011), and it is likely that cotton will remain important. There are also options to enhance food self-sufficiency and fodder availability through the incorporation of legumes such as cowpea. Yet fundamental improvements to the general policy and institutional environment will be needed (such as the finance system, investment in infrastructure, tariffs to increase farm gate prices) as a prerequisite for such technical options to be viable interventions. Our current work is focused on exploring such options together with farmers in the Koutiala region.

\section{Acknowledgment}

Funding for this research was provided by the McKnight Foundation $\left(\mathrm{N}^{\circ} 12-112\right.$ and 12-634) through the project 'Pathways to Agroecological Intensification of Sorghum and Millet Cropping Systems of Southern Mali' and by the CGIAR Research Program on Dryland Systems. We thank the Institut d'Economie Rurale (IER) for making available the panel dataset. Thanks also to three reviewers for their detailed comments that helped us to improve the manuscript.

\section{Appendix A. Supplementary data}

Supplementary data to this article can be found online at http://dx. doi.org/10.1016/j.agsy.2015.07.005.

\section{References}

Abdulai, A., \& CroleRees, A., 2001. Determinants of income diversification amongst rura households in Southern Mali. Food Policy 26, 437-452. http://dx.doi.org/10.1016/ S0306-9192(01)00013-6.

Andrieu, N., Vayssières, J., Corbeels, M., Blanchard, M., Vall, E., \& Tittonell, P., 2015. From farm scale synergies to village scale trade-offs: cereal crop residues use in an agropastoral system of the Sudanian zone of Burkina Faso. Agric. Syst. http://dx.doi.org 10.1016/j.agsy.2014.08.012.

Aparisi, A.M., Balié, J., Diallo, F., Komorowska, J., \& Keita, N., 2013. Impact of Mali's food and agricultural policies: an assessment of public expenditure and incentives. In: Elbehri, A. (Ed.), Rebuilding West Africa's Food Potential: Policies and Market Incentives for Smallholder-inclusive Food Value Chains. FAO/IFAD, Rome, pp. 153-184.

Bélières, J.-F., Benoit-Cattin, M., Barret, L., Djouara, H., \& Kébé, D., 2008. Les organisations de producteurs en zone cotonnière au Mali. Écon. Rural. Agric. Aliment. Territ. 22-38. http://dx.doi.org/10.4000/economierurale.498.

Benjaminsen, T.A., Aune, J.B., \& Sidibé, D., 2010. A critical political ecology of cotton and soil fertility in Mali. Geoforum 41, 647-656. http://dx.doi.org/10.1016/j.geoforum. 2010.03.003.

Blanchard, M., 2010. Gestion de la fertilité des sols et role du troupeau dans les systèmes coton-céréales-élevage au Mali-Sud. Savoirs techniques locaux et pratiques d'integration agriculture élevage (PhD thesis) Université Paris-Est Créteil Val Marne, Paris.

Bodnar, F., 2005. Monitoring for Impact: Evaluating 20 years of Soil and Water Conservation in Southern Mali (PhD thesis) Wageningen University, Wageningen. 
Britten, P., Marcoe, K., Yamini, S., \& Davis, C., 2006. Development of food intake patterns for the MyPyramid Food Guidance System. J. Nutr. Educ. Behav. 38, S78-S92.

Chopin, P., Blazy, J.-M., \& Doré, T., 2014. A new method to assess farming system evolution at the landscape scale. Agron. Sustain. Dev. 35, 325-337. http://dx.doi.org/10.1007/ s13593-014-0250-5.

Coulibaly, J., 2011. Diversification or Cotton Recovery in the Malian Cotton Zone: Effects on Households and Women (PhD Thesis) Purdue University.

De Ridder, N., Breman, H., van Keulen, H., \& Stomph, T.J., 2004. Revisiting a "cure against land hunger": soil fertility management and farming systems dynamics in the West African Sahel. Agric. Syst. 80, 109-131. http://dx.doi.org/10.1016/j. agsy.2003.06.004.

Degnbol, T., 2001. Inside government extension agencies: a comparison of four agencies in the Sikasso Region of Mali. In: Benjaminsen, T.A., Lund, C. (Eds.), Politics, Property and Production in the West African Sahel: Understanding Natural Resources Management. Nordic Africa Institute, pp. 100-116.

Djouara, H., Belières, J.F., \& Kébé, D., 2005. Les exploitations agricoles familiales de la zone cotonnière du mali face à la baisse des prix du coton graine. Cah. Agric. 15, 64-71.

Dorward, A., Anderson, S., Nava, Y., Pattison, J., Paz, R., Rushton, J., \& Sanchez Vera, E. 2009. Hanging in, stepping up and stepping out: livelihood aspirations and strategies of the poor. Dev. Pract. 19, 240-247.

Dufumier, M., \& Bainville, S., 2006. Le développement agricole du Sud-Mali face au désengagement de l'État. Afr. Contemp. 217, 121-133. http://dx.doi.org/10.3917/ afco.217.0121.

Ebanyat, P., de Ridder, N., de Jager, A., Delve, R.J., Bekunda, M.A., \& Giller, K.E., 2010 Drivers of land use change and household determinants of sustainability in smallholder farming systems of Eastern Uganda. Popul. Environ. 31, 474-506. http://dx. doi.org/10.1007/s11111-010-0104-2.

Fok, M., 2010. Facteurs d'efficacité des arrangements institutionnels en politique cotonnière africaine. Cah. Agric. 19, 68-74.

Gabre-Madhin, E.Z., \& Haggblade, S., 2004. Successes in African agriculture: results of an expert survey. World Dev. 32, 745-766. http://dx.doi.org/10.1016/j.worlddev.2003. 11.004 .

Generoso, R., 2015. How do rainfall variability, food security and remittances interact? The case of rural Mali. Ecol. Econ. 114, 188-198. http://dx.doi.org/10.1016/j. ecolecon.2015.03.009.

Gigou, J., Traoré, K., Giraudy, F., Coulibaly, H., Sogoba, B., \& Doumbia, M., 2006. Aménagement paysan des terres et réduction du ruissellement dans les savanes africaines. Cah. Agric. 15, 116-122.

Giller, K.E., Tittonell, P., Rufino, M.C., van Wijk, M.T., Zingore, S., Mapfumo, P., Adjei-Nsiah, S., Herrero, M., Chikowo, R., Corbeels, M., Rowe, E.C., Baijukya, F., Mwijage, A., Smith, J., Yeboah, E., van der Burg, W.J., Sanogo, O.M., Misiko, M., de Ridder, N., Karanja, S., Kaizzi, C., K'ungu, J., Mwale, M., Nwaga, D., Pacini, C., \& Vanlauwe, B., 2011. Communicating complexity: integrated assessment of trade-offs concerning soil fertility management within African farming systems to support innovation and development. Agric. Syst. 104, 191-203. http://dx.doi.org/10.1016/j.agsy.2010. 07.002 .

Hazell, P., Poulton, C., Wiggins, S., \& Dorward, A., 2010. The future of small farms: trajectories and policy priorities. World Dev. 38, 1349-1361. http://dx.doi.org/10.1016/j. worlddev.2009.06.012.

Headey, D.D., \& Jayne, T.S., 2014. Adaptation to land constraints: is Africa different? Food Policy 48, 18-33. http://dx.doi.org/10.1016/j.foodpol.2014.05.005.

Hertrich, V., \& Lesclingand, M., 2013. Adolescent migration in rural Africa as a challenge to gender and intergenerational relationships evidence from Mali. Ann. Am. Acad. Pol. Soc. Sci. 648, 175-188. http://dx.doi.org/10.1177/0002716213485356.

IER, 1988. Memento: l'Approche village à l'usage des encadreurs. DRSPR (Division de Recherche sur les Systèmes de Production Rurale, CMDT (Compagnie Malienne pour le Developpement des Textiles), IER(Institut d'Economie Rurale), KIT (Institut Royal des Regions Tropicales), Sikasso, Mali.

Iraizoz, B., Gorton, M., \& Davidova, S., 2007. Segmenting farms for analysing agricultura trajectories: a case study of the Navarra region in Spain. Agric. Syst. 93, 143-169. http://dx.doi.org/10.1016/j.agsy.2006.05.002.

Kaminski, J., Elbehri, A., \& Samake, M., 2013. An assessment of sorghum and millet in Mali and implications for competitive and inclusive value chains. In: Elbehri, A. (Ed.), Rebuilding West Africa's Food Potential: Policies and Market Incentives for Smallholderinclusive Food Value Chains. FAO/IFAD, Rome, pp. 481-500.

Kanté, S., 2001. Gestion de la fertilité des sols par classe d'exploitation au Mali-Sud (PhD thesis) Wageningen University, Wageningen.

Köbrich, C., Rehman, T., \& Khan, M., 2003. Typification of farming systems for constructing representative farm models: two illustrations of the application of multi-variate analyses in Chile and Pakistan. Agric. Syst. 76, 141-157. http://dx.doi.org/10.1016/S0308521X(02)00013-6.

Laroche Dupraz, C., \& Postolle, A., 2013. Food sovereignty and agricultural trade policy commitments: how much leeway do West African nations have? Food Policy 38 115-125. http://dx.doi.org/10.1016/j.foodpol.2012.11.005.

Mellor, J.W., 2014. High rural population density Africa - what are the growth requirements and who participates? Food Policy http://dx.doi.org/10.1016/j.foodpol.2014 03.002.

Mignolet, C., Schott, C., \& Benoît, M., 2007. Spatial dynamics of farming practices in the Seine basin: methods for agronomic approaches on a regional scale. Sci. Total Environ. 375, 13-32. http://dx.doi.org/10.1016/j.scitotenv.2006.12.004 (Human activity and material fluxes in a regional river basin: the Seine River watershed Seine Special Issue).

Muhammad-Lawal, A., \& Omotesho, O.A., 2008. Cereals and farming households' food security in Kwara State, Nigeria. Agric. J. 3, 235-240.

Mushongah, J., \& Scoones, I., 2012. Livelihood change in rural Zimbabwe over 20 years. J. Dev. Stud. 48, 1241-1257. http://dx.doi.org/10.1080/00220388.2012.671474.
Nubukpo, K., 2011. L'économie politique de la réforme des filières cotonnières d'Afrique de l'Ouest et du centre: vers la convergence des modes d'organisation? Mondes Dév. 155, 93-109. http://dx.doi.org/10.3917/med.155.0093.

Obare, G.A., Omamo, S.W., \& Williams, J.C., 2003. Smallholder production structure and rural roads in Africa: the case of Nakuru District, Kenya. Agric. Econ. 28, 245-254. http://dx.doi.org/10.1016/S0169-5150(03)00004-5.

Paassen, A. van, de Ridder, N., \& Stroosnijder, L., 2011. Role of an explorative model for learning about sustainable agricultural development in Burkina Faso. Int. J. Agric. Sustain. 9, 310-321. http://dx.doi.org/10.1080/14735903.2011.582360.

Pachpute, J.S., 2010. A package of water management practices for sustainable growth and improved production of vegetable crop in labour and water scarce SubSaharan Africa. Agric. Water Manag. 97, 1251-1258. http://dx.doi.org/10.1016/j. agwat.2009.11.009.

Pacini, G.C., Colucci, D., Baudron, F., Righi, E., Corbeels, M., Tittonell, P., \& Stefanini, F.M., 2014. Combining multi-dimensional scaling and cluster analysis to describe the diversity of rural households. Exp. Agric. 50, 376-397. http://dx.doi.org/10.1017/ S0014479713000495

Pijpers, R., 2014. Crops and carats: exploring the interconnectedness of mining and agriculture in Sub-Saharan Africa. Futures, "The Futures of Small-scale Mining in Sub-Saharan Africa" 62, Part A, pp. 32-39. http://dx.doi.org/10.1016/j.futures.2014. 01.012 .

Ripoche, A., Crétenet, M., Corbeels, M., Affholder, F, Naudin, K., Sissoko, F., Douzet, J.-M., \& Tittonell, P., 2015. Cotton as an entry point for soil fertility maintenance and food crop productivity in savannah agroecosystems-evidence from a long-term experiment in southern Mali. Field Crop Res. 177, 37-48. http://dx.doi.org/10.1016/j.fcr.2015.02. 013

Rufino, M.C., Tittonell, P., van Wijk, M.T., Castellanos-Navarrete, A., Delve, R.J., de Ridder, N., \& Giller, K.E., 2007. Manure as a key resource within smallholder farming systems: analysing farm-scale nutrient cycling efficiencies with the NUANCES framework. Livest. Sci. 112, 273-287. http://dx.doi.org/10.1016/j. livsci.2007.09.011

Rusinamhodzi, L., Corbeels, M., Nyamangara, J., \& Giller, K.E., 2012. Maize-grain legume intercropping is an attractive option for ecological intensification that reduces climatic risk for smallholder farmers in central Mozambique. Field Crop Res. 136, 12-22. http://dx.doi.org/10.1016/j.fcr.2012.07.014.

Sanogo, O.M., 2011. Le lait, de l'or blanc? Amélioration de la productivité des exploitations mixtes cultures-élevage à travers une meilleure gestion et alimentation des vaches laitières dans la zone de Koutiala, Mali (PhD thesis) Wageningen University, Wageningen.

Sanogo, O.M., de Ridder, N., \& van Keulen, H., 2010. Diversité et dynamique des exploitations agricoles mixtes agriculture-élevage au sud du Mali. Cah. Agric. 19, 185-193.

Sassen, M. Sheil, D. Giller, K.E \& ter Braak, C.JF, 2013. Complex contexts and dynamic drivers: understanding four decades of forest loss and recovery in an East African protected area. Biol. Conserv. 159, 257-268. http://dx.doi.org/10.1016/j.biocon. 2012.12.003.

Schaller, N., Lazrak, E.G., Martin, P., Mari, J.-F., Aubry, C., \& Benoît, M., 2011. Combining farmers' decision rules and landscape stochastic regularities for landscape modelling. Landsc. Ecol. 27, 433-446. http://dx.doi.org/10.1007/s10980-011-9691-2.

Senthilkumar, K. Bindraban, P.S., de Ridder, N., Thiyagarajan, T.M., \& Giller, K.E., 2012. Impact of policies designed to enhance efficiency of water and nutrients on farm households varying in resource endowments in south India. NJAS - Wagening. J. Life Sci. 59, 41-52. http://dx.doi.org/10.1016/j.njas.2012.01.002.

Soumaré, M., Bazile, D., Kouressy, M., Diallo, K., \& Diakité, C.H., 2008. Diversité agroécosystémique et devenir des céréales traditionnelles au sud du Mali. Cah. Agric. 17, 79-85.

Stoate, C., Báldi, A., Beja, P., Boatman, N.D. Herzon, I. van Doorn, A, de Snoo, G.R., Rakosy, L., \& Ramwell, C., 2009. Ecological impacts of early 21 st century agricultural change in Europe - a review. J. Environ. Manag. 91, 22-46. http://dx.doi.org/10.1016/j. jenvman.2009.07.005

Tarawali, S.A., Singh, B., Gupta, S., Tabo, R., Harris, F., Nokoe, S., Fernandez-Rivera, S. Bationo, A., Manyong, V., Makinde, K., \& Odion, E., 2002. Cowpea as a key factor for a new approach to integrated crop-livestock systems research in the dry savannas of West Africa. In: Fatokun, C.A., Tarawali, S.A., Singh, B.B., Kormawa, P.M., Tamo, M. (Eds.), Challenges and Opportunities for Enhancing Sustainable Cowpea Production. IITA, Ibadan, pp. 233-251

Tefft, J., 2010. Mali's white revolution: smallholder cotton, 1960-2006. In: Haggblade, S., Hazell, P.B.R. (Eds.), Successes in African Agriculture: Lessons for the Future. International Food Policy Research Institute (IFPRI), pp. 113-162.

Tittonell, P., \& Giller, K.E., 2013. When yield gaps are poverty traps: the paradigm of ecological intensification in African smallholder agriculture. Field Crop Res. 143, 76-90. http://dx.doi.org/10.1016/j.fcr.2012.10.007.

Tittonell, P., van Wijk, M.T., Herrero, M., Rufino, M.C., de Ridder, N., \& Giller, K.E., 2009. Beyond resource constraints - exploring the biophysical feasibility of options for the intensification of smallholder crop-livestock systems in Vihiga district, Kenya. Agric. Syst. 101, 1-19. http://dx.doi.org/10.1016/j.agsy.2009.02.003

Tittonell, P., Muriuki, A., Shepherd, K.D., Mugendi, D., Kaizzi, K.C., Okeyo, J., Verchot, L., Coe, R., \& Vanlauwe, B., 2010. The diversity of rural livelihoods and their influence on soil fertility in agricultural systems of East Africa - a typology of smallholder farms. Agric. Syst. 103, 83-97. http://dx.doi.org/10.1016/j.agsy. 2009.10.001.

Traore, B., van Wijk, M.T., Descheemaeker, K., Corbeels, M., Rufino, M.C., \& Giller, K.E., 2014. Evaluation of climate adaptation options for Sudano-Sahelian cropping systems. Field Crop Res. 156, 63-75. http://dx.doi.org/10.1016/j.fcr.2013.10.014.

Valbuena, D., Groot, J.C.J., Mukalama, J., Gérard, B., \& Tittonell, P., 2014. Improving rural livelihoods as a "moving target": trajectories of change in smallholder farming 
systems of Western Kenya. Reg. Environ. Chang. 1-13. http://dx.doi.org/10.1007/ s10113-014-0702-0.

Van Keulen, H., \& Breman, H., 1990. Agricultural development in the West African Sahelian region: a cure against land hunger? Agric. Ecosyst. Environ. 32, 177-197.

Zingore, S., Murwira, H.K., Delve, R.J., \& Giller, K.E., 2007. Influence of nutrient management strategies on variability of soil fertility, crop yields and nutrient balances on smallholder farms in Zimbabwe. Agric. Ecosyst. Environ. 119, 112-126. http://dx. doi.org/10.1016/j.agee.2006.06.019.

Zorom, M., Barbier, B., Mertz, O., \& Servat, E., 2013. Diversification and adaptation strategies to climate variability: a farm typology for the Sahel. Agric. Syst. 116, 7-15. http:// dx.doi.org/10.1016/j.agsy.2012.11.004. 